\title{
RNA-Seq analysis of Clerodendrum inerme (L.) roots in response to salt stress
}

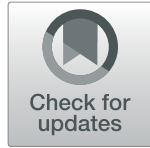

Yuping Xiong ${ }^{1,2+}$, Haifeng Yan ${ }^{3 \dagger}$, Hanzhi Liang ${ }^{1,2}$, Yueya Zhang ${ }^{1,2}$, Beiyi Guo ${ }^{1,2}$, Meiyun Niu ${ }^{1,2}$, Shuguang Jian ${ }^{1}$ Hai Ren ${ }^{1}$, Xinhua Zhang ${ }^{1}$, Yuan $\mathrm{Li}^{1}$, Songjun Zeng ${ }^{1}$, Kunlin Wu${ }^{1}$, Feng Zheng ${ }^{1}$, Jaime A. Teixeira da Silva ${ }^{4}$ and Guohua $\mathrm{Ma}^{1 *}$

\begin{abstract}
Background: Clerodendrum inerme (L.) Gaertn, a halophyte, usually grows on coastal beaches as an important mangrove plant. The salt-tolerant mechanisms and related genes of this species that respond to short-term salinity stress are unknown for us. The de novo transcriptome of $C$. inerme roots was analyzed using next-generation sequencing technology to identify genes involved in salt tolerance and to better understand the response mechanisms of $C$. inerme to salt stress.

Results: Illumina RNA-sequencing was performed on root samples treated with $400 \mathrm{mM} \mathrm{NaCl}$ for $0 \mathrm{~h}, 6 \mathrm{~h}, 24 \mathrm{~h}$, and $72 \mathrm{~h}$ to investigate changes in C. inerme in response to salt stress. The de novo assembly identified 98,968 unigenes. Among these unigenes, 46,085 unigenes were annotated in the NCBI non-redundant protein sequences (NR) database, 34,756 sequences in the Swiss-Prot database and 43,113 unigenes in the evolutionary genealogy of genes: Non-supervised Orthologous Groups (eggNOG) database. 52 Gene Ontology (GO) terms and 31 Kyoto Encyclopedia of Genes and Genomes (KEGG) pathways were matched to those unigenes. Most differentially expressed genes (DEGs) related to the GO terms "single-organism process", "membrane" and "catalytic activity" were significantly enriched while numerous DEGs related to the plant hormone signal transduction pathway were also significantly enriched. The detection of relative expression levels of 9 candidate DEGs by qRT-PCR were basically consistent with fold changes in RNA sequencing analysis, demonstrating that transcriptome data can accurately reflect the response of $C$. inerme roots to salt stress.

Conclusions: This work revealed that the response of $C$. inerme roots to saline condition included significant alteration in response of the genes related to plant hormone signaling. Besides, our findings provide numerous salttolerant genes for further research to improve the salt tolerance of functional plants and will enhance research on salt-tolerant mechanisms of halophytes.
\end{abstract}

Keywords: Halophyte, Clerodendrum inerme (L.) Gaertn, Salt stress, Transcriptome

\section{Background}

Soil salinization is a serious threat to the environment and agricultural productivity worldwide. Research into salt tolerance and its underlying mechanisms has been carried out in many plant species, such as rice $[1,2]$, melon [3], maize [4], tobacco [5] and tomato [6]. Investigations of plant salt tolerance are crucial for the

\footnotetext{
* Correspondence: magh@scib.ac.cn

†Yuping Xiong and Haifeng Yan contributed equally to this work.

${ }^{1}$ Guangdong Provincial Key Laboratory of Applied Botany, South China

Botanical Garden, the Chinese Academy of Sciences, Guangzhou 510650,

China

Full list of author information is available at the end of the article
}

sustainable development of saline agriculture. To achieve this, salt-tolerant species are essential for salt stress research $[7,8]$. Halophytes, which account for about $1 \%$ of the world's total flora, can survive in highly saline environments and possess salt-responsive genes and proteins to encounter the adverse effects of salinity. Halophytes are further divided into hydro-halophytes and xerohalophytes. Hydro-halophytes grow in aquatic conditions or wet soil, such as mangroves and salt-marsh species along coastlines whereas xero-halophytes grow in habitats where the soil is always saline and dries out periodically causing water to become unavailable to the plant,

(c) The Author(s). 2019 Open Access This article is distributed under the terms of the Creative Commons Attribution 4.0 International License (http://creativecommons.org/licenses/by/4.0/), which permits unrestricted use, distribution, and reproduction in any medium, provided you give appropriate credit to the original author(s) and the source, provide a link to the Creative Commons license, and indicate if changes were made. The Creative Commons Public Domain Dedication waiver (http://creativecommons.org/publicdomain/zero/1.0/) applies to the data made available in this article, unless otherwise stated. 
such as succulent species in desert areas $[9,10]$. Having natural salt tolerance, halophytic species represent ideal material to explore complex physiological and molecular mechanisms of salt tolerance, such as Thellungiella halophila [11, 12], Halogeton glomeratus [13] and Suaeda glauca [14].

The mechanisms of salt tolerance in halophytes have been gradually revealed over the past few years. The salt tolerance of a halophyte is determined by effective coordination between various physiological processes, metabolic pathways and gene networks under salt stress, including activation of antioxidant enzymes, induction and modulation of plant hormones, biosynthesis of compatible solutes and osmoprotectants, selective accumulation, exclusion of ions, and other mechanisms [15-18]. Furthermore, numerous genes that were isolated from halophytes have also been exploited by various modern biotechnological techniques to identify the genes that function in salt tolerance, including genes encoding for transcription factors $[19,20]$, the $\mathrm{Na}^{+} / \mathrm{H}^{+}$antiporter gene $[21,22]$ and genes encoding antioxidant enzymes $[23,24]$. The existence of these genes enhances the tolerance of plants to salt and provides more choices for the improvement of salt tolerance in crops. However, considering the variety of halophyte species, our understanding of the mechanism underlying salt tolerance in halophyte is limited. Novel processes or genes may exist in different halophyte species.

Clerodendrum inerme (L.) Gaertn, a synonym of Volkameria inermis L. (http://www.theplantlist.org/; last accessed May 28, 2019), which is distributed in the South of China, India and Southeast Asia to Northern Oceania, usually grows on coastal beaches as a mangrove plant and be used for coastal afforestation. In fact, $C$. inerme also displays tremendous potential for ecological development. A few reports of $C$. inerme have indicated its value based on phytochemical composition [25-27] and medicinal properties [28-30]. C. inerme is used by coastal people as a poultice for skin disease and to treat wounds [31]. Not only it has been listed as a hydro-halophyte for use in saline agriculture in Pakistan [32], but it has also been recorded as a medicinal halophyte in the Chinese Germplasm Resources of Halophytes (http://www.grhc.sdnu.edu.cn/; last accessed May 28, 2019). Several mangrove species with exceptional salt tolerance have been reported, including Rhizophora stylosa [33], Sonneratia alba [34] and Avicennia officinalis [35]. Novel genes that involved in salt response of those species revealed in above reports. As a mangrove species with important ecological and scientific value, salt tolerance mechanism in $C$. inerme is unclear. The potential candidate genes have not been identified in this halophyte species.
In recent years, RNA-seq, as an important strategy in the investigation of the expression of a large number genes in a given tissue at a given time point, has been widely used to research the responses of plants to abiotic stress [36, 37], particularly salt stress [38, 39]. And de novo assembly makes it possible for a detailed genetic analysis to be performed on any organism [40] and has been applied to a number of halophytes to uncover their mechanisms of salt tolerance. This technology can reveal candidate genes and key pathways involved in salt tolerance by analyzing differentially expressed genes (DEGs) and RNA-seq functional annotation. Transcriptome analysis reveals that several levels of biochemical and molecular responses are associated with salt tolerance in Suaeda maritima, including the remodeling of cell walls and the modification of membrane lipids at the structural level and the accumulation of glycine betaine and the sequestration and exclusion of $\mathrm{Na}^{+}$at the cellular level [41]. Genes related to membrane transport, osmoprotection, redox metabolism or protein synthesis were differentially expressed in Beta vulgaris ssp. maritima in response to salt stress [42]. In Glehnia littoralis, DEGs encoding transcription factors or related to plant hormone signaling, calcium signaling, and phospholipase signaling, were responsive to $\mathrm{NaCl}$ treatment [43]. RNAseq technology assists researchers to establish a better understanding of molecular networks in plant in response to salt stress.

\section{Results}

Effect of salt stress on activity of antioxidant enzymes, $\mathrm{H}_{2} \mathrm{O}_{2}$ content and ion content

Under $600 \mathrm{mM} \mathrm{NaCl}$ treatment, the roots of C. inerme turned brown after $24 \mathrm{~h}$ treatment and gradually grow wilt. While, under $400 \mathrm{mM} \mathrm{NaCl}$ treatment, no visible damage were observed on C. inerme roots after $24 \mathrm{~h}$ treatment. The roots grow lightly brown at 10 days (Fig. 1a). Thus, $400 \mathrm{mM} \mathrm{NaCl}$ was chosen for the further test. In the $400 \mathrm{mM} \mathrm{NaCl}$ treatment, root superoxide dismutase (SOD) and catalase (CAT) activity increased sharply and a sharp increase in SOD activity was observed from $6 \mathrm{~h}$ to $48 \mathrm{~h}$, but CAT activity decreased after $24 \mathrm{~h}$. Unlike SOD and CAT, root peroxidase (POD) activity changed slightly and showed no significant changes after $\mathrm{NaCl}$ treatment (Fig. 1b, c, d). In contrast, hydrogen peroxide $\left(\mathrm{H}_{2} \mathrm{O}_{2}\right)$ content continued to decline after $1 \mathrm{~h}$ treatment (Fig. 1e). The $\mathrm{Na}^{+}$content was significantly higher in $\mathrm{NaCl}$-treated roots than in the control, and increased sharply at $6 \mathrm{~h}, 24 \mathrm{~h}$ treatment. After a peak at $48 \mathrm{~h}$ treatment, a decline of $\mathrm{Na}^{+}$ content was observed in C. inerme roots at $72 \mathrm{~h}$ treatment (Fig. 1f). By contrast, the $\mathrm{K}^{+}$content showed significant decline under $\mathrm{NaCl}$ treatment. The downtrend became slow after $6 \mathrm{~h}$ treatment (Fig. 1g). The wild fluctuations of antioxidant enzymes activity and ion accumulation in $C$. 


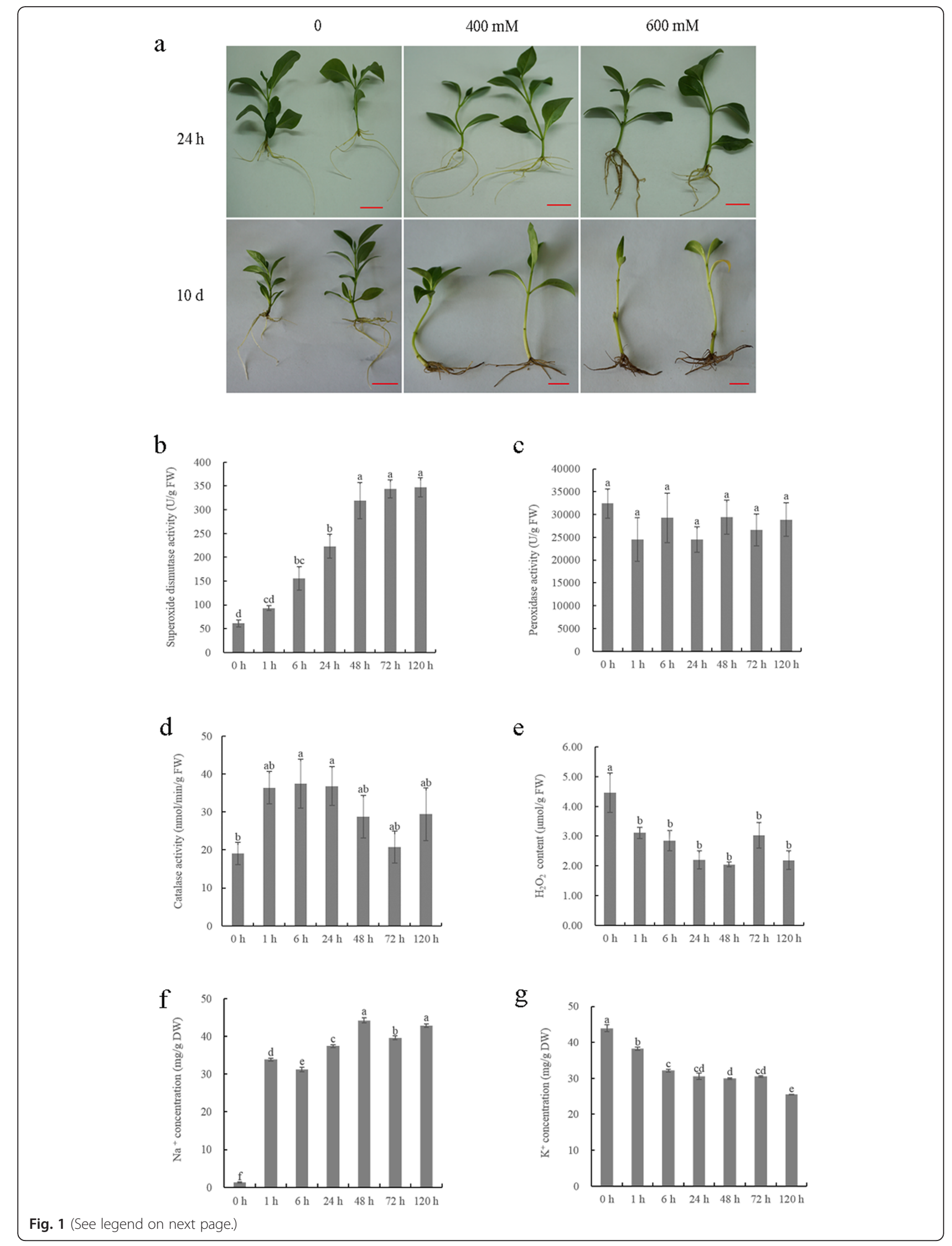


(See figure on previous page.)

Fig. 1 Effect of $\mathrm{NaCl}$ treatment on Clerodendrum inerme growth. (a) Growth phenotype of C. inerme under control and stress conditions. The red bars represent one centimeter. (b, $\mathbf{c}, \mathbf{d}, \mathbf{e}, \mathbf{f}$ and $\mathbf{g})$ Root antioxidant enzyme activity (b: SOD, c: POD, d: CAT), $\mathrm{H}_{2} \mathrm{O}_{2}$ content $(\mathbf{e})$ and $\mathrm{Na}^{+}(\mathbf{f}), \mathrm{K}^{+}(\mathbf{g})$ content in C. inerme at $0 \mathrm{~h}, 1 \mathrm{~h}, 6 \mathrm{~h}, 24 \mathrm{~h}, 48 \mathrm{~h}, 72 \mathrm{~h}$ and $120 \mathrm{~h}$ after treatments. Different letters indicate statistically significant differences based on Duncan's multiple range test $(P<0.05)$ for the designated treatments

inerme roots under $\mathrm{NaCl}$ stress suggest that a substantial change in salt responsive gene expression might occur at $6 \mathrm{~h}, 24 \mathrm{~h}$ and $72 \mathrm{~h}$ after $400 \mathrm{mM} \mathrm{NaCl}$ treatment. Therefore, these root samples (i.e., $0 \mathrm{~h}, 6 \mathrm{~h}, 24 \mathrm{~h}$ and $72 \mathrm{~h}$ ) were subjected to RNA-seq analysis.

\section{De novo assembly and quality assessment of transcriptome}

Twelve cDNA libraries prepared from three repeat RNA samples from the $0 \mathrm{~h}, 6 \mathrm{~h}, 24 \mathrm{~h}$, and $72 \mathrm{~h}$ treatment were sequenced on the Illumina HiSeq platform and 692,669, 572 raw reads were obtained. The sequenced raw data in this article was submitted to the SRA at the NCBI database with the following accession numbers: SRR8203779, SRR8203780, SRR8203777, SRR8203778, SRR8203783, SRR8203784, SRR8203781, SRR8203782, SRR8203785, SRR8203786, SRR8203775, and SRR8203776. After removing low-quality regions and adapters, we obtained a total of 683,948,928 clean reads with Q20>96.11\% (Table 1). The quality of transcripts and unigene length distribution are shown in Fig. 2.

\section{Transcriptome annotation}

Using the best hits found by BLAST with $E$ values $<1 \mathrm{e}-$ 5 , an inferred putative function was assigned to the sequences. A total of 46,085 (46.57\%) unigenes were matched to known genes in the NR database, and 34,756 (35.12\%) sequences had best hits in the Swiss-Prot database (Table 2). As shown in Fig. 3, the E-value distribution of the top hits in the NR database showed that $38.28 \%$ of the sequences were mapped to known genes in plants with best hits ( $E$ value $<1 \mathrm{e}-45$ ) (Fig. 3a), and approximately $37.76 \%$ of the unigenes showed $>80 \%$ similarity with deposited sequences (Fig. 3b). Approximately $73.31 \%$ of the annotated unigenes were assigned with a best score to sequences from the top seven species (Fig. 3c): Sesamum indicum (44.66\%), Erythranthe guttata (16.72\%), Dorcoceras hygrometricum (4.11\%), Prunus persica (3.08\%), Vitis vinifera (1.99\%), Cajanus cajan (1.67\%) and Coffea canephora (1.08\%).

A total of 22,473 unigenes were assigned to GO terms that described biological processes, molecular functions, and cellular components (Fig. 4). Most annotated unigenes in biological processes were involved in "metabolic process", "cellular process", 'single-organism process", and "localization and biological regulation". In the category of molecular functions, the highest portion of annotated unigenes were enriched in terms of "binding", "catalytic activity" and "transporter activity". In the cellular component, more annotated unigenes were categorized in the "membrane", "cell" and "cell part".

We obtained a KEGG pathway annotation for 5969 unigenes, and 31 pathways were assorted based on five branches, including metabolism, genetic information processing, environmental information processing, cellular processes and organismal systems (Fig. 5). On the

Table 1 Statistics of output sequencing in Clerodendrum inerme

\begin{tabular}{|c|c|c|c|c|c|c|}
\hline Samples & Reads (No.) & Clean reads (No.) & Bases (bp) & Clean data (bp) & N (\%) & Q20 (\%) \\
\hline oh-1 & $60,802,270$ & $60,008,714$ & $9,120,340,500$ & $8,912,712,572$ & 0.00139 & 97.57 \\
\hline $0 \mathrm{~h}-2$ & $57,493,894$ & $56,789,814$ & $8,624,084,100$ & $8,431,598,540$ & 0.001364 & 97.69 \\
\hline $0 \mathrm{~h}-3$ & $56,866,282$ & $55,934,266$ & $8,529,942,300$ & $8,313,133,758$ & 0.002491 & 96.21 \\
\hline $6 \mathrm{~h}-1$ & $55,327,066$ & $54,686,334$ & $8,299,059,900$ & $8,098,537,576$ & 0.001451 & 97.79 \\
\hline $6 \mathrm{~h}-2$ & $55,683,662$ & $55,033,118$ & $8,352,549,300$ & $8,155,979,860$ & 0.001475 & 97.8 \\
\hline $6 \mathrm{~h}-3$ & $58,976,774$ & $58,281,832$ & $8,846,516,100$ & $8,646,526,566$ & 0.001437 & 97.73 \\
\hline $24 \mathrm{~h}-1$ & $60,813,298$ & $60,098,036$ & $9,121,994,700$ & $8,903,035,660$ & 0.001583 & 97.79 \\
\hline $24 h-2$ & $57,868,180$ & $57,194,542$ & $8,680,227,000$ & $8,506,194,364$ & 0.001434 & 97.72 \\
\hline $24 h-3$ & $58,931,324$ & $58,021,340$ & $8,839,698,600$ & $8,634,386,222$ & 0.002948 & 96.11 \\
\hline $72 \mathrm{~h}-1$ & $55,592,334$ & $54,926,346$ & $8,338,850,100$ & $8,166,663,782$ & 0.001337 & 97.57 \\
\hline $72 \mathrm{~h}-2$ & $57,207,480$ & $56,526,470$ & $8,581,122,000$ & $8,408,351,478$ & 0.001331 & 97.53 \\
\hline $72 h-3$ & $57,107,008$ & $56,448,116$ & $8,566,051,200$ & $8,386,908,366$ & 0.00143 & 97.63 \\
\hline
\end{tabular}

Reads $($ No. $)=$ total number of reads. Clean reads $($ No. $)=$ number of high quality sequence reads. Bases $(b p)=$ total number of bases. Clean data $=$ number of high quality sequence bases. The Q20 percentage is the proportion of nucleotides with a quality value $>20$. $\mathrm{N}(\%)=$ the proportion of unknown nucleotides in clean reads 


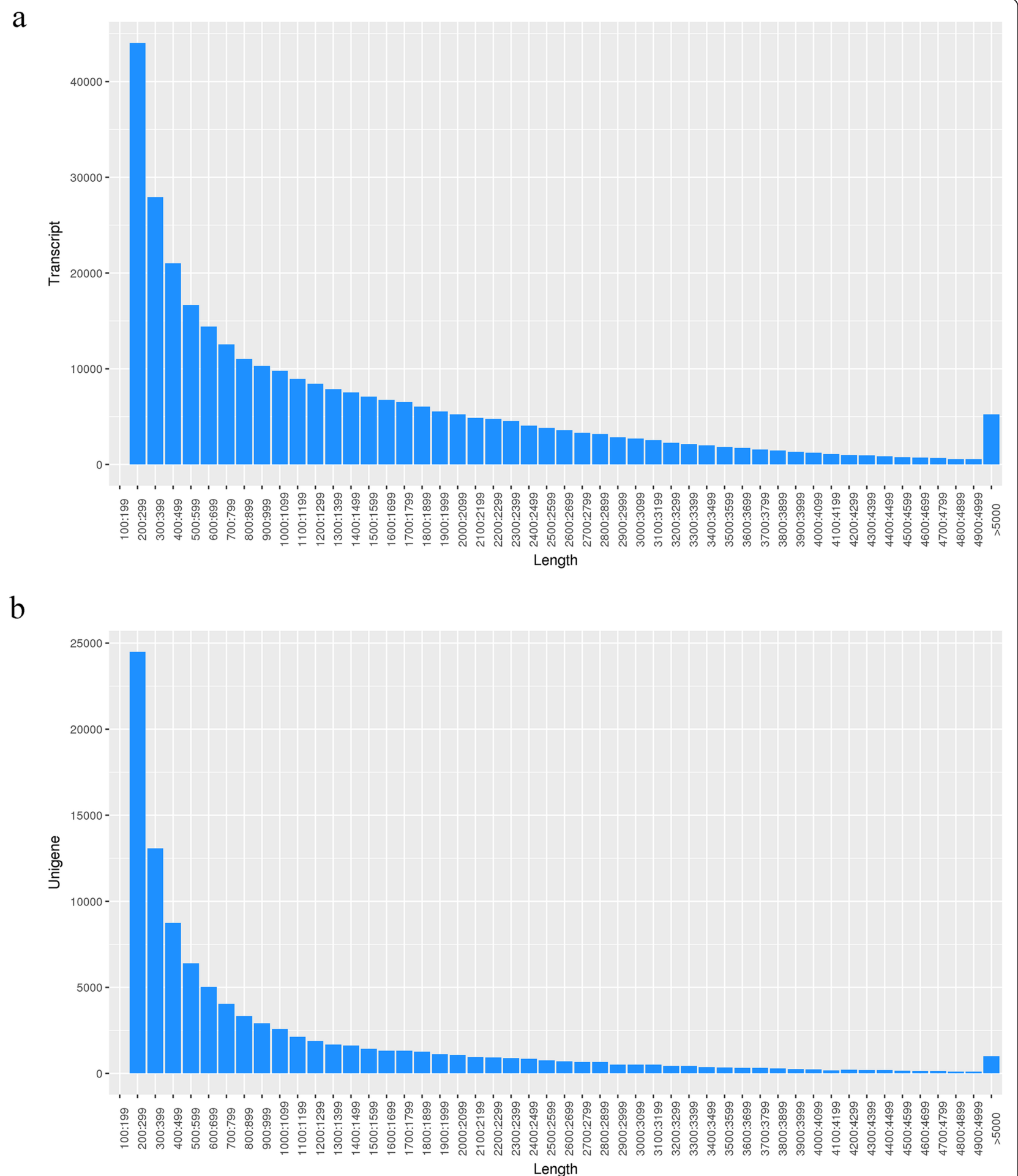

Fig. 2 Random distribution of transcript (a) and unigene (b) length in Clerodendrum inerme. The $x$-axis indicates length of the transcript or unigene. The $y$-axis indicates the number of transcripts or unigenes

basis of KEGG analysis, most unigenes were annotated into sub-branches of "carbohydrate metabolism", "translation" and "signal transduction".
Unigenes were also aligned to the eggNOG database to predict and classify possible functions. A total of 43,113 unigenes were distributed into 25 categories (Fig. 6). 
Table 2 The results of annotation in Clerodendrum inerme

\begin{tabular}{lll}
\hline Annotation databases & Isoform numbers & Percentage (\%) \\
\hline NR & 46,085 & 46.57 \\
GO & 22,473 & 22.71 \\
KEGG & 5969 & 6.03 \\
eggNOG & 43,113 & 43.56 \\
Swissprot & 34,756 & 35.12 \\
In all databases & 4396 & 4.4 \\
\hline
\end{tabular}

Among them, the NOG category "general function prediction only" represented the largest group, followed by "function unknown", "signal transduction mechanisms", "posttranslational modification, protein turnover, chaperones", "transcription", "replication, recombination and repair", and "carbohydrate transport and metabolism". The smallest group was "cell motility".

\section{Gene expression and analysis of differentially expressed genes}

The analysis of gene expression density (Additional file 6 : Fig. S1) showed that most transcripts were activated by salt stress, and the $\log 10$ (FPKM) ranged from 0 to 1 , as assessed by boxplot analysis (Additional file 7 : Fig. S2). The operational stability and reliability of this experiment were illustrated with a high Pearson's correlation coefficient $\left(R^{2}>0.9\right)$ among the three biological replicates at each time point (Additional file 8 : Fig. S3). These analyses suggested that the gene expression levels in this experiment were reliable for the next step of the analysis.

Hierarchical clustering was used to analyze the expression patterns of DEGs under different experimental conditions. As shown in Fig. 7, the DEGs were divided into 15 main clusters. The highest number of up-regulated genes was observed at $24 \mathrm{~h}(10,460)$ and fewest at $72 \mathrm{~h}$ $(2,797)$. The percentage of annotated DEGs in the NR database in the $6 \mathrm{~h}, 24 \mathrm{~h}$, and $72 \mathrm{~h}$ libraries was 73.06, 72.20 and $76.05 \%$, respectively. A total of 4186 common DEGs were obtained from $6 \mathrm{~h}, 24 \mathrm{~h}$, and $72 \mathrm{~h}$ libraries (Fig. 8a), including 1626 up-regulated genes in all stages (Fig. 8b). There were many more DEGs at $24 \mathrm{~h}(19,767)$ than at $6 \mathrm{~h}(12,826)$ and $72 \mathrm{~h}(7,315)$ (Fig. $8 \mathrm{c})$.

GO term and KEGG pathway enrichment analysis of DEGs Although the plantlets were treated with $\mathrm{NaCl}$ for different periods of time, the significant enrichment GO

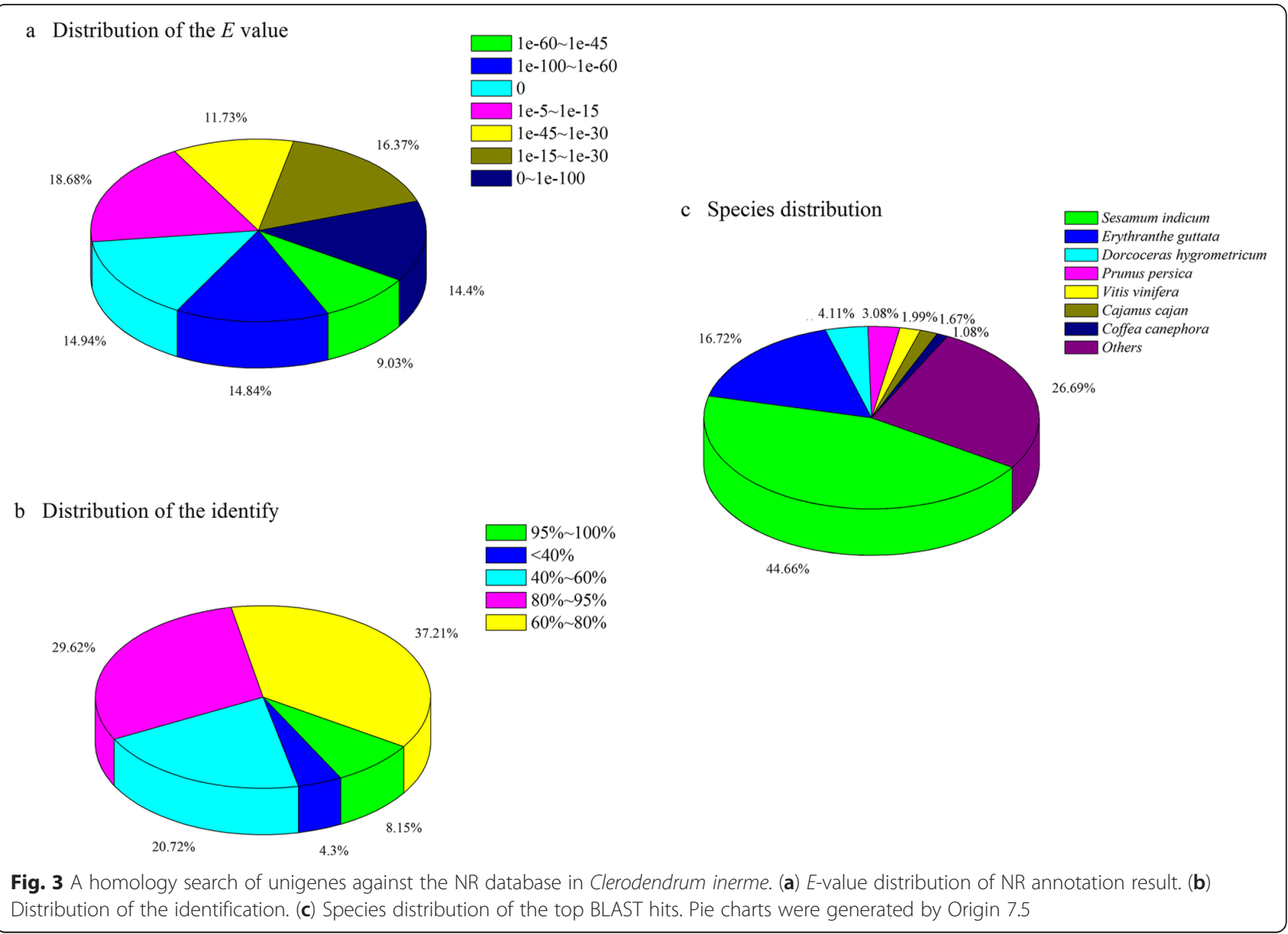




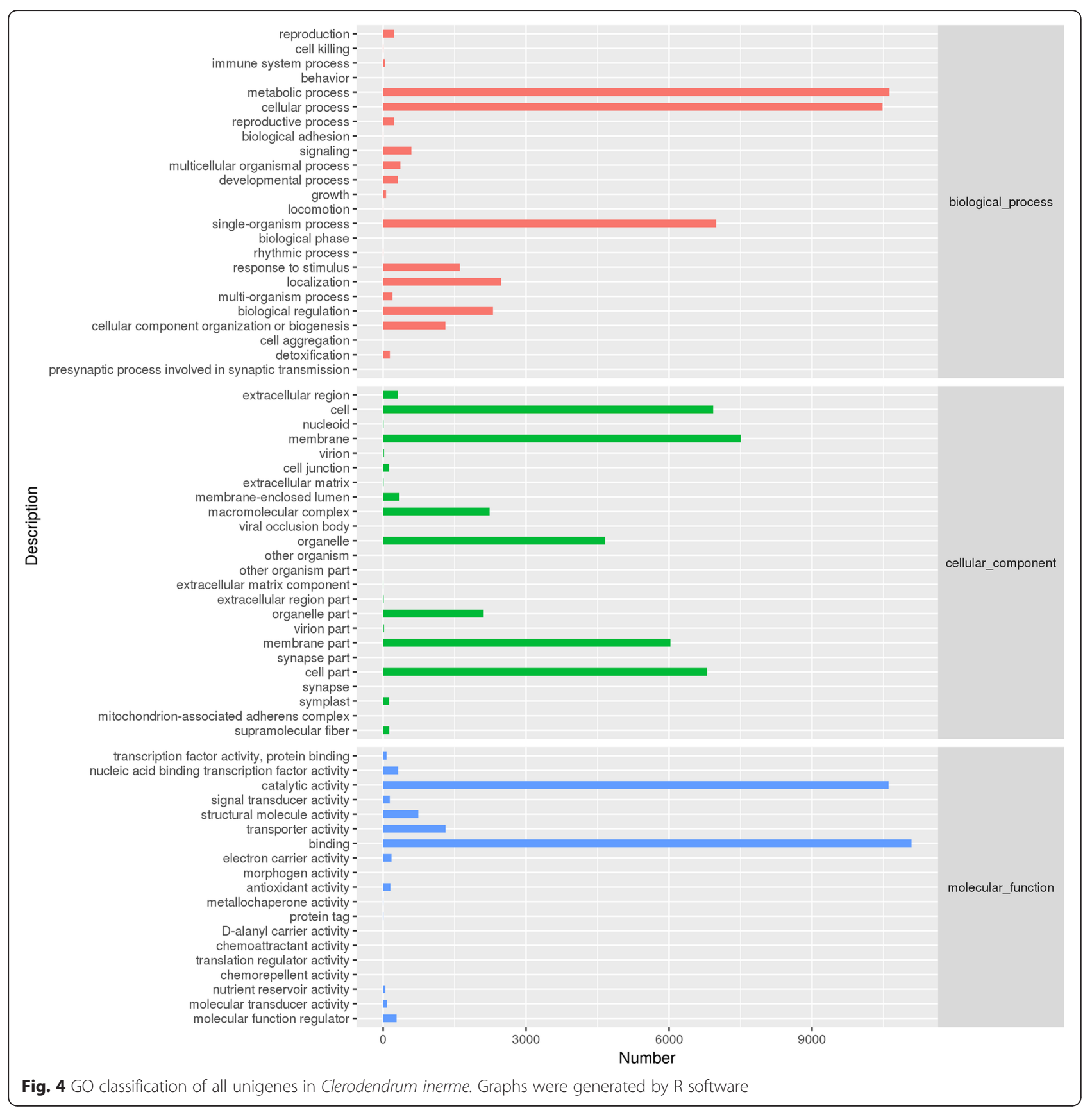

terms in those stages was very similar (Additional file 1 : Table S1). In biological processes, the dominant term was "single-organism process". In the cellular component, the dominant term was "membrane". Among the molecular functions, the dominant term was "catalytic activity". The common DEGs were significantly enriched more in "single-organism metabolic process" and "oxidation-reduction process" of biological processes, "membrane" and "membrane part" of the cellular component, and "catalytic activity" and "cation binding" of molecular functions. Otherwise, the number and categories of extremely enriched GO terms differed between stages. At $6 \mathrm{~h}, 53$ enriched GO terms were identified, in which "oxidation-reduction process", "intrinsic component of membrane" and "oxidoreductase activity" term were highly enriched. At $24 \mathrm{~h}, 25$ enriched GO terms were identified, in which "recognition of pollen", "integral component of membrane" and "catalytic activity" term were highly enriched. The most number of enriched GO terms was observed at $72 \mathrm{~h}$, with $79 \mathrm{GO}$ terms related to "oxidation-reduction process", "photosystem" and "tetrapyrrole binding" being highly enriched. 


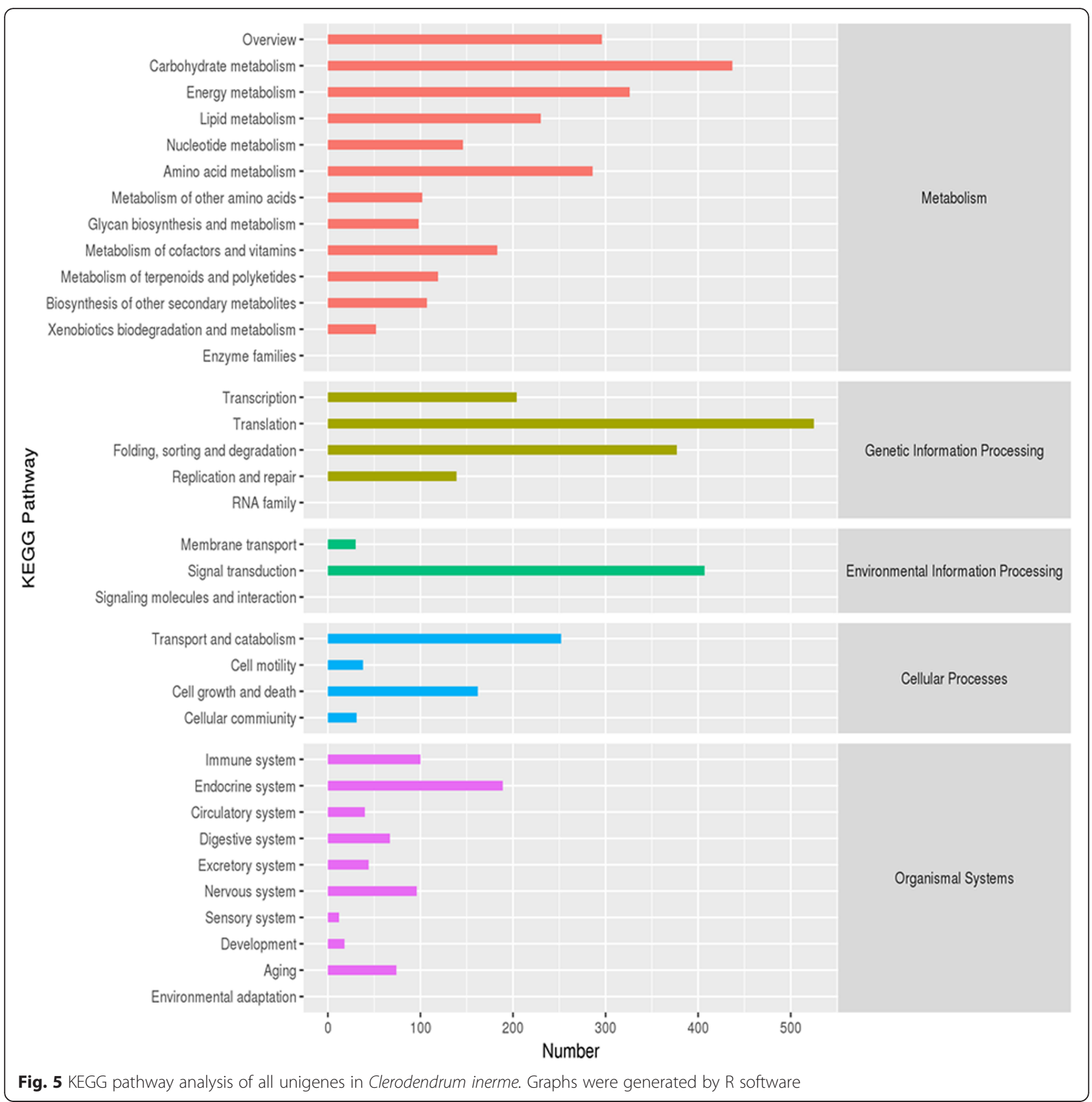

Compared with $0 \mathrm{~h}$, the DEGs of $6 \mathrm{~h}, 24 \mathrm{~h}$, and $72 \mathrm{~h} \mathrm{li-}$ braries were assigned to 242, 261, and 209 sub-branches of the KEGG pathway, respectively. The significantly enriched pathways in $\mathrm{NaCl}$-treated samples at $6 \mathrm{~h}, 24 \mathrm{~h}$, and $72 \mathrm{~h}$ were shown in Fig. 9 and Additional file 2 : Table S2. Unlike the enriched GO terms, the number of enriched pathways peaked at $6 \mathrm{~h}$ with 40 pathways, followed by $72 \mathrm{~h}$ with 23 pathways, and $24 \mathrm{~h}$ with 22 pathways. The enriched pathways with more genes than other pathways were similar in $6 \mathrm{~h}, 24 \mathrm{~h}$, and $72 \mathrm{~h}$ libraries, including "plant hormone signal transduction", "carbon metabolism", "photosynthesis", "phenylpropanoid biosynthesis", "starch and sucrose metabolism", and "plant-pathogen interaction". The identical DEGs were also significantly enriched more in "plant hormone signal transduction", followed by "phenylpropanoid biosynthesis".

Eight signaling transduction pathways related to hormones, auxin, cytokinin, gibberellin, abscisic acid (ABA), ethylene, brassinosteroid, jasmonic acid and salicylic acid (SA) (Additional files 9, 10, 11, Figs. S4-S6), were activated under salt stress, including 80 DEGs with 27 up-regulated genes and 53 down-regulated genes at $6 \mathrm{~h}, 80$ DEGs with 36 up-regulated genes and 44 down-regulated genes at 24 $\mathrm{h}$, and 55 DEGs with 13 up-regulated genes and 42 down- 

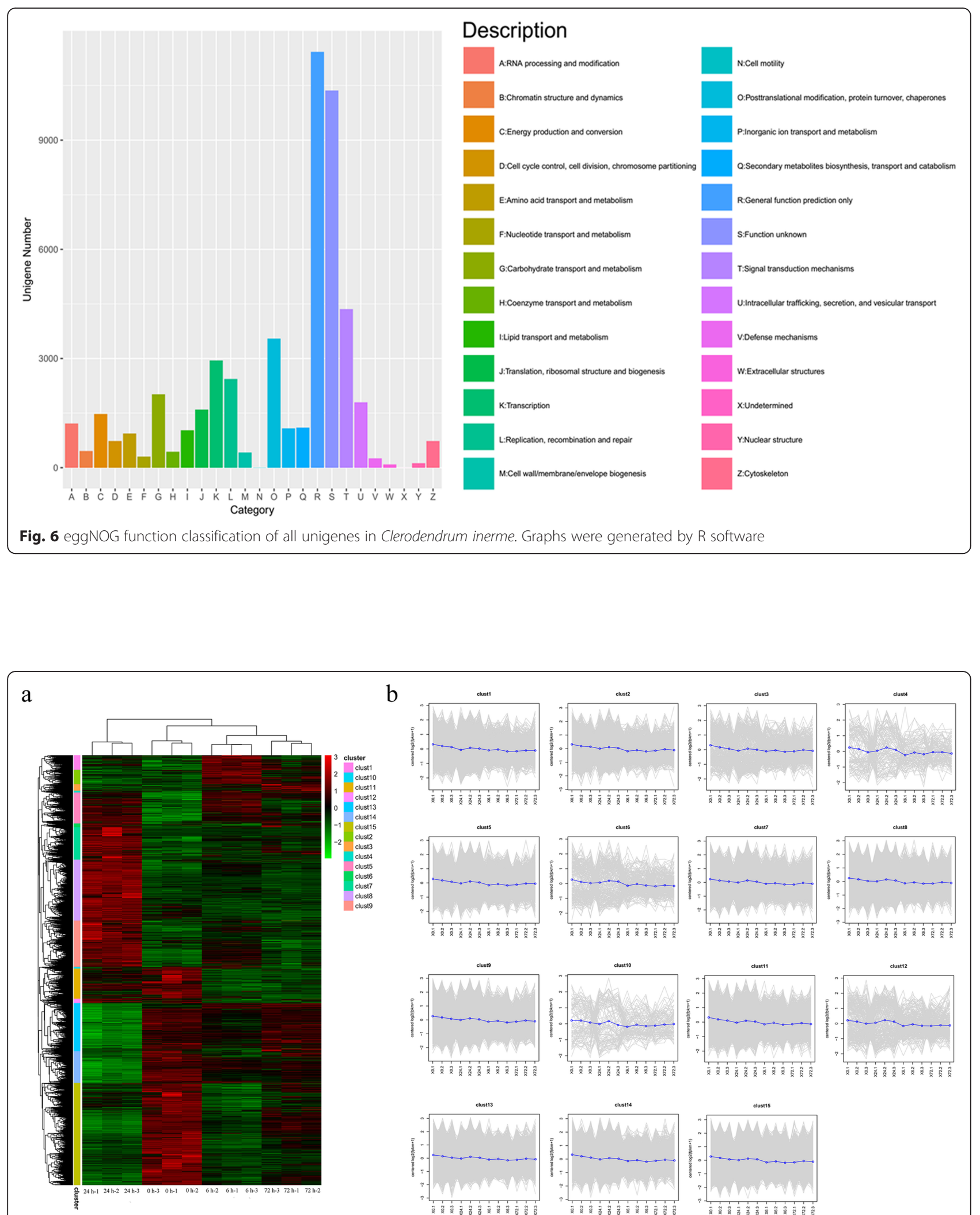

Fig. 7 Clerodendrum inerme hierarchical cluster analysis of DEGs in different treatments. (a) Heat map of the expression profiles of DEGs. (b) The expression analysis of DEGs in 15 clusters. The $x$-axis represents the time point after each treatment with three replicates, while the $y$-axis represents the value of the expression level $(\log 2($ FPKM +1$))$ 


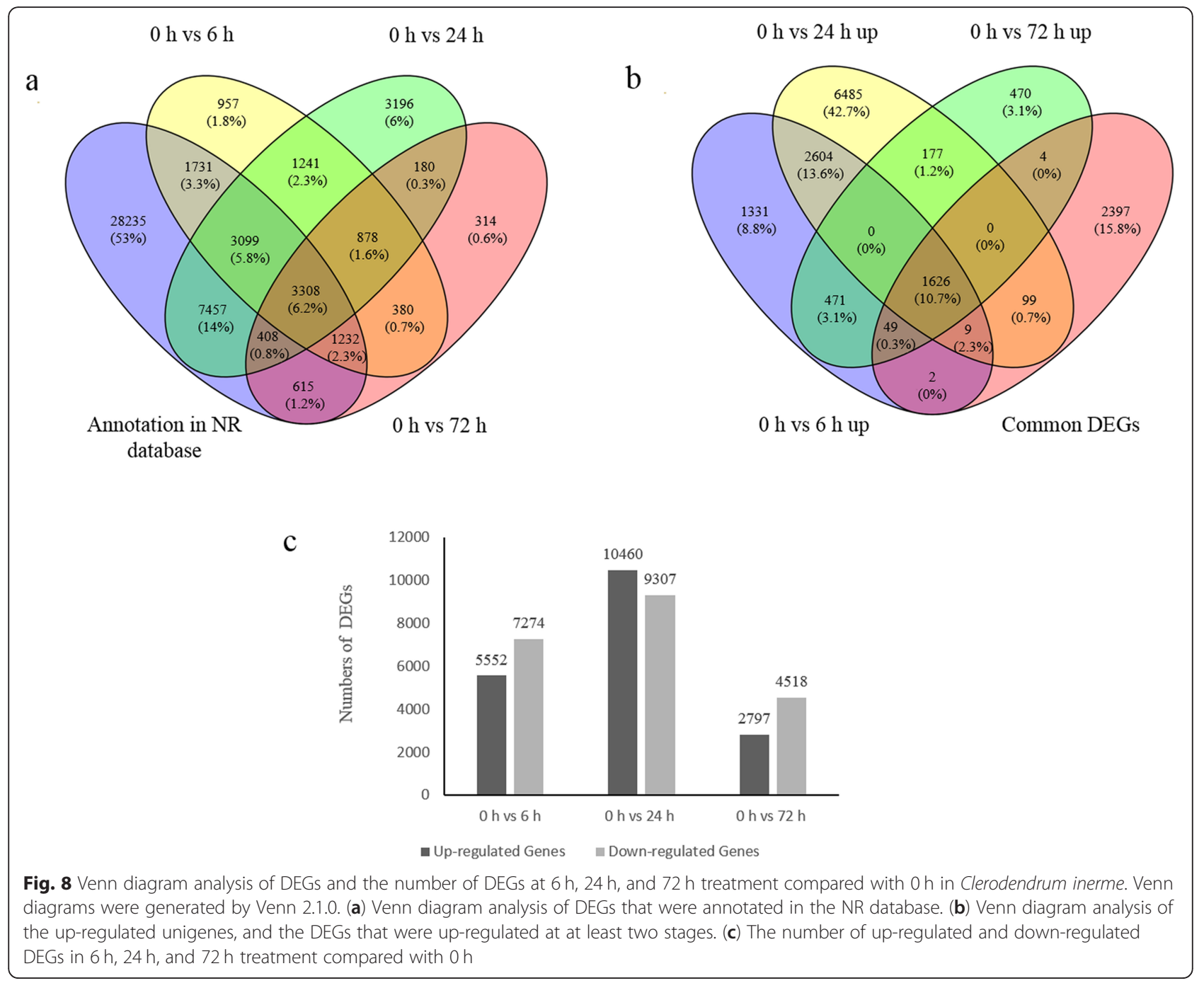

regulated genes DEGs at $72 \mathrm{~h}$. In addition, 35 common DEGs with nine up-regulated genes and 26 down-regulated genes were significantly enriched in "plant hormone signal transduction" at $6 \mathrm{~h}, 24 \mathrm{~h}$ and $72 \mathrm{~h}$, respectively. In the plant hormone signal transduction pathway, genes annotated as ethylene-responsive transcription factor (ERF), pathogenesisrelated (PR) protein and auxin-related protein were identified (Additional file 3 : Table S3).

\section{Genes involved in antioxidant enzymes system and ion transport}

A total of 17, 10 and 114 genes were annotated to SOD, CAT and POD, respectively. Most of these genes were mapped to the GO terms "removal of superoxide radicals", "response to oxidative stress", "cellular oxidant detoxification", "oxidation-reduction process", and others. In addition, we also identified genes related to ascorbate peroxidase and glutathione peroxidase involved in these terms (Additional file 4: Table S4). Moreover, some DEGs were enriched in "oxidation-reduction process". Besides, numerous genes related to sodium and potassium ion transport were also identified in $C$. inerme roots under $\mathrm{NaCl}$ treatment. Those genes were mapped to the GO terms "transmembrane transport", "ion transport", "integral component of membrane" and "potassium ion transport" (Additional file 4: Table S4).

\section{Quantitative reverse transcription-polymerase chain reaction analysis of gene expression}

To further validate the results from the Illumina sequencing data, nine candidate DEGs were selected for quantitative reverse transcription-polymerase chain reaction (qRT-PCR) analysis of root samples that were treated with $400 \mathrm{mM} \mathrm{NaCl}$ for $0 \mathrm{~h}, 6 \mathrm{~h}, 24 \mathrm{~h}$, and $72 \mathrm{~h}$. In the four treatment stages, the trend of expression of the unigenes from qRT-PCR and RNA sequencing analysis were largely consistent (Fig. 10). These results demonstrate that the transcriptome data accurately reflects the response of $C$. inerme roots to salt stress. 


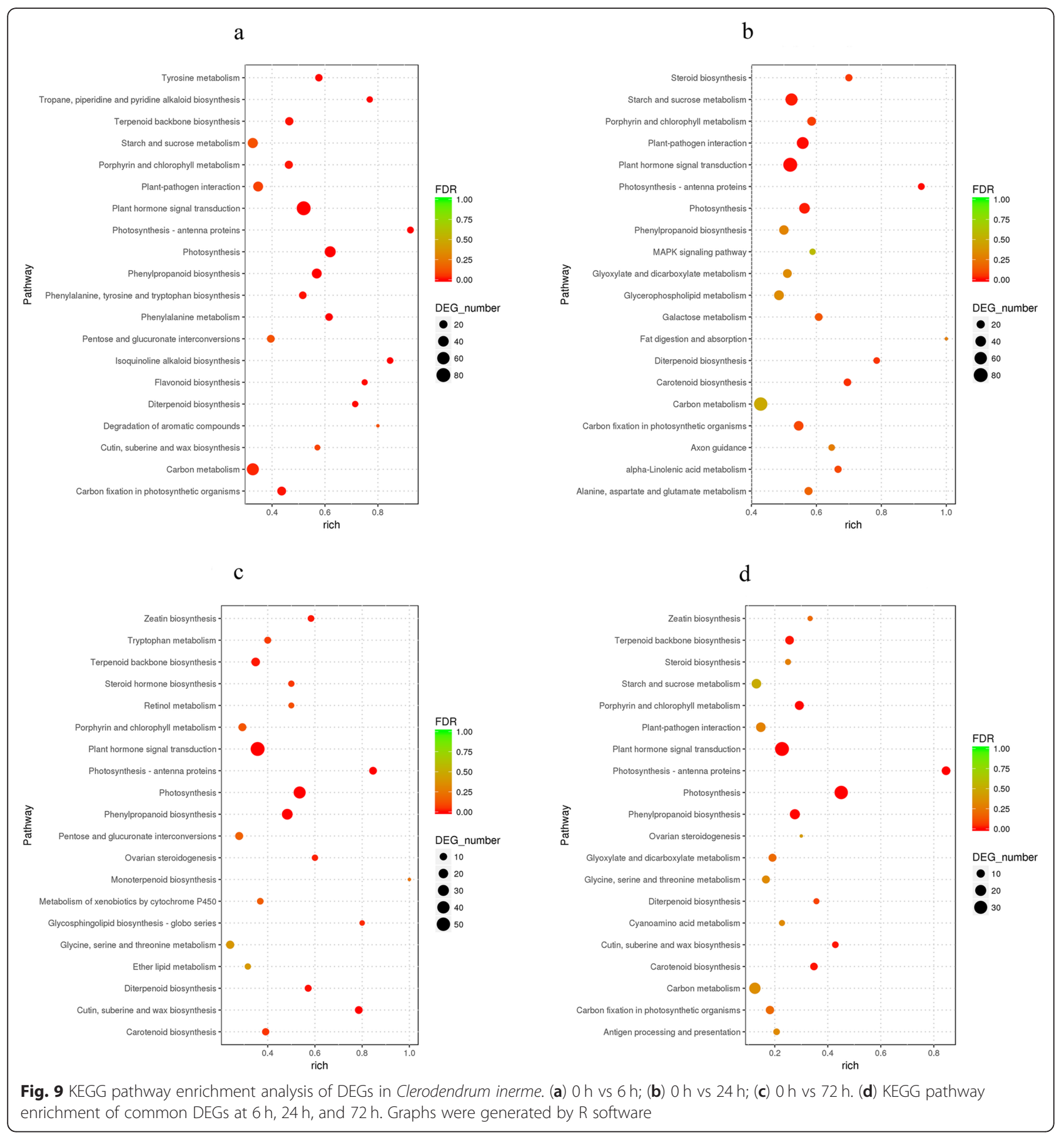

\section{Discussion}

Most studies have investigated long-term salt stress response in plants, and focused on various organs' responses to salt stress, including leaves, roots and callus. For example, the dynamic transcriptome of poplar (Populus simonii $\times$ Populus nigra) leaves was investigated after exposure to $\mathrm{NaCl}$ for $3 \mathrm{~d}, 6 \mathrm{~d}$ and $9 \mathrm{~d}$ [44]. Transcriptomic changes to barley microspore-derived embryogenic callus was profiled in the period of cellular adaptation to stress after $21 \mathrm{~d}$ of culture in $\mathrm{NaCl}$ supplemented medium [45]. Furthermore, the shoots and roots of salt mash euhalophyte, Salicornia europaea, collected from short- and long-term stress (exposure to $200 \mathrm{mM} \mathrm{NaCl}$ for $0 \mathrm{~h}, 12 \mathrm{~h}$ and $7 \mathrm{~d}$ ) were used to perform high-throughput deep sequencing [46]. Although these analyses involved different treatments and organs, the genes and pathways of these species involved in salt tolerance at different stages were consistently revealed. 


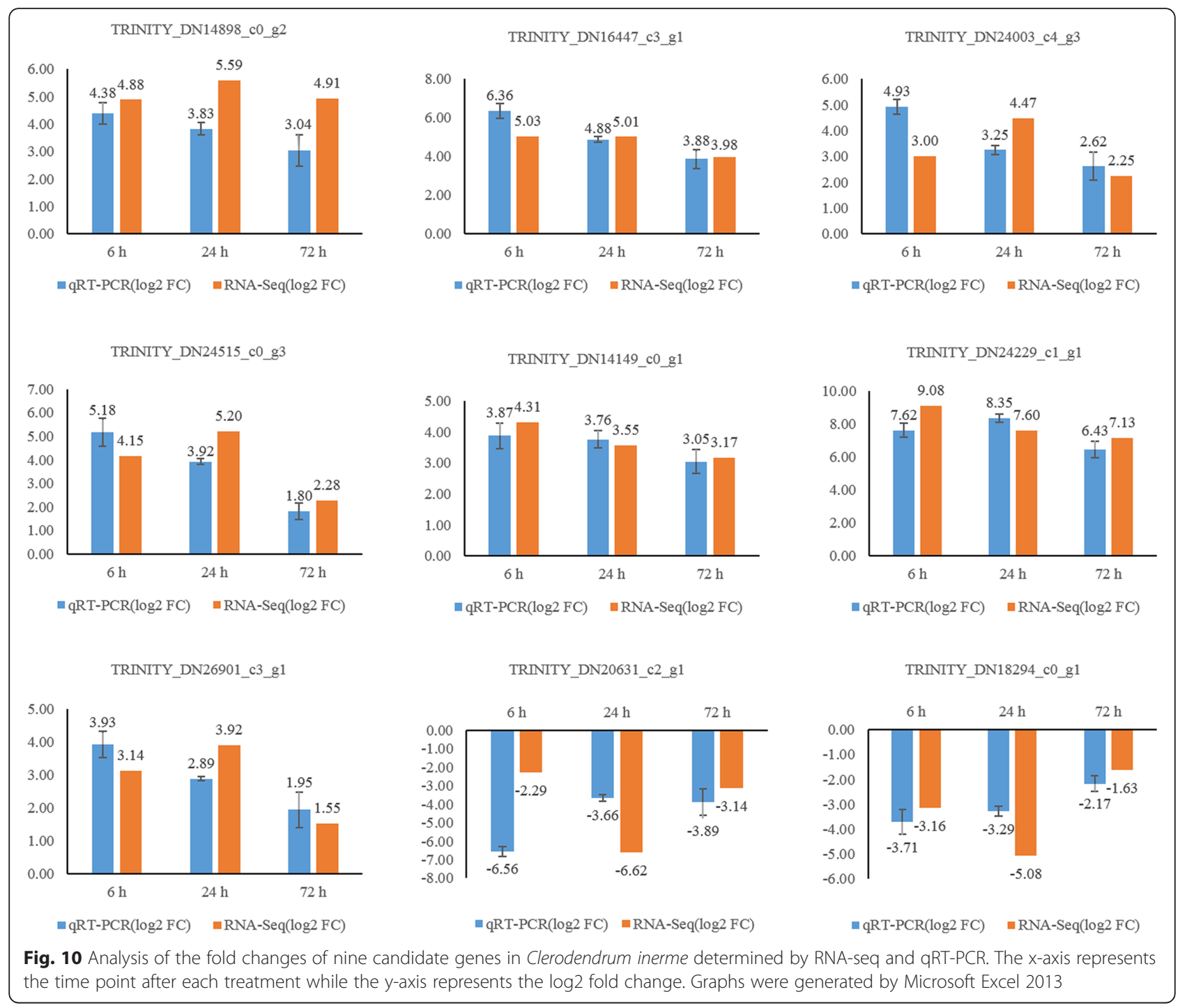

Compared with aboveground organs, roots do not contain specialized structures such as salt glands, or photosynthetic systems. Given their simple structure, roots are highly sensitive to salt and are the primary site of perception to the soil environment. Roots are thus an essential organ to investigate a plant's response to salt stress $[47,48]$. A series of responses in roots are activated by short-term salt stress $[49,50]$. These responses might be an effective means for a plant to resist salt stress. For these reasons, we performed a transcriptome analysis of $C$. inerme roots in response to short-term salt stress.

Physiological changes in roots at early stages after exposure to salt stress are also an indicator of substantial changes in salt-responsive gene expression in response to short-term salt stress. In Populus tomentosa, the accumulation of $\mathrm{H}_{2} \mathrm{O}_{2}$ and concentration of hormones changed significantly at $6 \mathrm{~h}, 12 \mathrm{~h}$, and $24 \mathrm{~h}$, and root samples at those time points were subjected to RNA-seq analysis to understand the short-term salt stress response, revealing the high enrichment of DEGs involved in $\mathrm{H}_{2} \mathrm{O}_{2}$ and hormone production [51]. In Zoysia japonica, oxidative stress caused by $\mathrm{H}_{2} \mathrm{O}_{2}$ was visible throughout roots after $30 \mathrm{~min}$ exposure to $\mathrm{NaCl}$, and numerous candidate genes related to early responses to salt stress were revealed by de novo assembly of the Japanese lawngrass root transcriptome [52]. The activity of antioxidant enzymes in plants is closely related with tolerance to salt $[53,54]$. Salt stress induces the accumulation of toxic compounds in cells, such as the superoxide radical and $\mathrm{H}_{2} \mathrm{O}_{2}$, both of which are reactive oxygen species (ROS). SOD converts the superoxide radical into $\mathrm{H}_{2} \mathrm{O}_{2}$ and $\mathrm{H}_{2} \mathrm{O}_{2}$ is further scavenged by POD, CAT or other enzymes [55-57]. The $\mathrm{Na}^{+} / \mathrm{K}^{+}$balance in intracellular is also an important factor for plant salt tolerance. It is essential for the cytosol to maintain a low concentration of 
$\mathrm{Na}^{+}$or a low $\mathrm{Na}^{+} / \mathrm{K}^{+}$ratio in plant cells under salt stress [58]. In the present study, the activity of antioxidant enzymes in $C$. inerme roots increased rapidly after subjected to $\mathrm{NaCl}$ stress for 1, 6, 24, 48, 72, $120 \mathrm{~h}$. SOD and CAT activity of $C$. inerme roots changed sharply or maintained the highest level after $\mathrm{NaCl}$ treatment at $6 \mathrm{~h}$, $24 \mathrm{~h}$, and $72 \mathrm{~h}$. The dramatic changes of $\mathrm{Na}^{+}$and $\mathrm{K}^{+}$accumulation were also observed at $6 \mathrm{~h}, 24 \mathrm{~h}$, and $72 \mathrm{~h}$ treatment. A series of salt response system might be activated at those time points. Using root samples at above time point, we identified genes related to antioxidant enzymes and ion transport, and those genes were involved in the ROS scavenger enzymatic system and ion transport in response to $\mathrm{NaCl}$ stress. This finding indicates that the time point at which antioxidant enzyme activity and ion accumulation changes significantly could serve as a valid marker to indicate substantial changes in saltresponsive gene expression in short-term adaptation to salt stress in $C$. inerme roots.

Significantly enriched GO terms and KEGG pathways may differ among plant species, but they still retain some similarities, despite the short- or long-term nature of salt stress. In Raphanus sativus roots treated with $200 \mathrm{mM} \mathrm{NaCl}$ for $48 \mathrm{~h}$, DEGs were enriched in the GO terms "response to stimulus" and "single-organism process", and the "plant-pathogen interaction" and "plant hormone signal transduction" pathways [59]. After treating Helianthus tuberosus roots with $150 \mathrm{mM}$ $\mathrm{NaCl}$ for $15 \mathrm{~d}$, most DEGs were mapped to "single-organism metabolic process" and "catalytic activity". Numerous genes and proteins differentially expressed in $H$. tuberosus roots under salt stress had enriched GO terms "carbohydrate metabolism", "ribosome activation" and "translation" [60]. In this study, the dominant enriched GO terms that were identified were "single-organism process", "membrane" and "catalytic activity", and more DEGs were significantly enriched in the "plant hormone signal transduction", "carbon metabolism" and "plantpathogen interaction" pathways. This result indicates that these GO terms and pathways were significantly involved in the plants response to salt stress, particularly in $C$. inerme roots.

Genes related to "plant hormone signal transduction" pathway has been verified to be involved in plant response to salt stress in several species. In Iris halophila shoots exposed to salt stress, the maximum number of DEGs displayed a significant enrichment in the "plant hormone signal transduction" pathway while the expression levels of genes related to cytokinin, gibberellin, ethylene, and SA signal transduction were also upregulated in response to salt stress [61]. Compared with a salt-sensitive maize inbred line (L29), salt-tolerant inbred line L87 exhibited specific regulatory mechanisms related to salt tolerance. L87 exhibited increased expression of auxin, cytokinine, ethylene, ABA and SA biosynthetic genes involved in growth and protection. In contrast, L29 exhibited relatively lower expression of these genes [62]. Thus, genes, especially DEGs involved in the plant hormone signal transduction pathway, may also be an important category in research related to plant resistance to salt stress. We found that more DEGs were enriched in the "plant hormone signal transduction" pathway in the response of $C$. inerme roots to salt stress. Among them, nine DEGs performed up-regulated pattern at all the time points $(6 \mathrm{~h}, 24 \mathrm{~h}$ and $72 \mathrm{~h})$, so were 26 down-regulated genes. Those genes may be involved in a complex regulation system in the resistance to salt stress in $C$. inerme roots.

In $C$. inerme roots, we identified several DEGs annotated as ERF genes in the "plant hormone signal transduction" pathway after $\mathrm{NaCl}$ treatment. ERFs, which are plant-specific transcription factors, are involved in multiple biological processes, especially in abiotic stress [63]. TaERF3, a wheat ERF transcription factor, positively regulated the adaptation of wheat to salt and drought stress. Compared to untransformed wheat, the seedlings of TaERF3-overexpressing transgenic lines exhibited significantly enhanced tolerance to both salt and drought stress. Conversely, TaERF3-silenced wheat plants displayed more sensitivity to salt and drought stress than control plants [64]. Over-expression of the poplar transcription factor ERF76 gene in tobacco enhanced its salt tolerance. Compared to the control, the transgenic line showed a significant increase in seed germination rate, plant height, root length, and fresh weight, as well as in relative water content, activity of antioxidant enzymes, and proline content after salt stress [65]. The role of ERFs in the response of $C$. inerme roots to salt stress needs additional verification.

PR proteins are always induced by various types of pathogens such as viruses, bacteria, and fungi and also by the application of chemicals that mimic the effect of pathogen infection or induce similar stresses. Based on their primary structure, serological activity, and biological activity, PR proteins have been classified into 17 different families, ranging from PR-1 to PR-17, and some members of those families are involved in the plant's response to salt stress [66-68]. AhSIPR10, a salinityinduced PR class 10 protein, was isolated from callus cell lines of peanut (Arachis hypogaea). The overexpression of AhSIPR10 enhanced tolerance to salt, heavy metal and mannitol-induced drought stress in transgenic tobacco line [69]. Transgenic plants overexpressing AhSIPR10 in banana showed better photosynthetic efficiency and less membrane damage in the presence of $\mathrm{NaCl}$ and mannitol than wild type plants [70]. This result indicates that PR proteins participate in a variety of stress responses. We also identified several PR proteins 
in C. inerme roots after $\mathrm{NaCl}$ treatment. Those PR proteins were annotated on the SA signal transduction pathway of phenylethylamine metabolism. The differential expression level of those genes at all stages may indicate a certain function of PR proteins in the resistance of $C$. inerme roots to salt stress.

Auxin plays an important role in the regulation of plant growth and development, and auxin-related genes are also involved in plant stress and defense responses [71]. Under desiccation, cold, and salt stress, 41 members of auxin-related gene families were differentially expressed in rice under at least one abiotic stress condition while three genes were differentially expressed under all three stress conditions [72]. In Saccharum narenga, 175 genes encoding auxin-related proteins were identified in the leaves in response to drought treatment. DEGs encoding auxin response factors and auxininduced proteins were up-regulated in sugarcane leaves in response to water deficit, and genes encoding indole3 -acetic acid were down-regulated in leaves from drought-treated samples compared to the control [73]. A halophyte is able to complete its life cycle at a high salt concentration. This may be closely related to the regulation of auxin. In $C$. inerme roots, we identified DEGs annotated as "auxin-induced protein", "auxin-responsive protein", "auxin response factor" and "auxin transporter-like protein" in the plant hormone signal transduction pathway. Those genes also participated in the response of $C$. inerme roots to salt stress. Exploration of the regulation of auxin-related genes in plants' response to salt stress will uncover the crosstalk between signal transduction pathways involving phytohormones and plant salt tolerance.

\section{Conclusions}

In the present study, the transcriptome of $C$. inerme roots was analyzed using RNA-seq technology to explore the mechanism involved in salt tolerance. The enriched GO terms and KEGG pathways that are involved in the response of $C$. inerme roots to short-term salinity were revealed. Genes related to the plant hormone signal transduction pathway were significantly involved in the response of $C$. inerme roots to saline conditions. Our findings provide numerous salt tolerant genes that can be applied in further research to improve the salt tolerance of functional plants and will enhance research on salt-tolerant mechanisms of halophytes.

\section{Methods}

\section{Plant material and experimental design}

Adult $C$. inerme plants were collected from Wenchang $\left(108^{\circ} 21^{\prime}\right.$ to $111^{\circ} 03^{\prime} \mathrm{E}, 19^{\circ} 20^{\prime}$ to $\left.20^{\circ} 10^{\prime} \mathrm{N}\right)$, Hainan Province and maintained at South China Botanical Garden (SCBG) in Guangzhou, China, in 2017. Samples were collected and identified by Professor Shuguang Jian. A voucher specimen was deposited in the SCBG herbarium (voucher number 784713). Stem segments from mother plants were collected as explants and were washed under running tap water for $60 \mathrm{~min}$. Excised stems were surface sterilized with $75 \%(\mathrm{v} / \mathrm{v})$ ethanol for $30 \mathrm{~s}$, rinsed in sterile distilled water, and dipped in $0.1 \%$ $(\mathrm{w} / \mathrm{v})$ mercuric chloride solution for $8 \mathrm{~min}$ followed by five or six rinses with sterile distilled water. After that, they were placed on sterile filter paper and allowed to dry briefly in air. Stems were cut into $2.0 \mathrm{~cm}$ long segments, each carrying one or more nodes, and inoculated onto Murashige and Skoog (MS) [74] basal medium containing $2.21 \mu \mathrm{M}$ 6-benzyladenine (BA, Solarbio, Beijing, China) and $0.55 \mu \mathrm{M} \alpha$-naphthaleneacetic acid (NAA, Sigma-Aldrich, St. Louis, USA). Axillary shoots developed within $30 \mathrm{~d}$. Individuals axillary shoots $(\sim 2$ $\mathrm{cm}$ long) were inoculated onto MS medium with $1.0 \mu \mathrm{M}$ indole-3-butyric acid (IBA, Sigma-Aldrich) to initiate roots [75]. Plantlets with more than six roots were transferred to culture jars containing $15 \mathrm{~mL}$ of liquid MS medium and allowed to adapt for a week, then transferred to culture jars containing $15 \mathrm{~mL}$ of liquid MS medium with 400 and $600 \mathrm{mM} \mathrm{NaCl}$, respectively. Roots at $0 \mathrm{~h}, 1 \mathrm{~h}, 6 \mathrm{~h}, 24 \mathrm{~h}, 48 \mathrm{~h}, 72 \mathrm{~h}$, and $120 \mathrm{~h}$ after $400 \mathrm{mM}$ $\mathrm{NaCl}$ treatment were harvested for analysis.

All media contained $30 \mathrm{~g} / \mathrm{L}$ sucrose and $0.6 \%(\mathrm{w} / \mathrm{v})$ agar, and $\mathrm{pH}$ was adjusted to 5.8-6.0, then autoclaved at $121^{\circ} \mathrm{C}$ for $20 \mathrm{~min}$. Culture jars $(11 \mathrm{~cm}$ high; $6.5 \mathrm{~cm}$ diameter; $280 \mathrm{~mL}$ ) were placed in an air-conditioned culture room at $25 \pm 2{ }^{\circ} \mathrm{C}$ with a 12 -h photoperiod under $100 \mu \mathrm{M} \mathrm{m}^{-2} \mathrm{~s}^{-1}$ fluorescent light (Philips, Tianjing, China) and $50-70 \%$ relative humidity.

\section{Antioxidant enzyme activity and $\mathrm{H}_{2} \mathrm{O}_{2}$ assay}

Roots at $0 \mathrm{~h}, 1 \mathrm{~h}, 6 \mathrm{~h}, 24 \mathrm{~h}, 48 \mathrm{~h}, 72 \mathrm{~h}$, and $120 \mathrm{~h}$ after exposure to $\mathrm{NaCl}$ treatment were harvested as $\sim 0.1 \mathrm{~g}$ fresh weight (FW) with three biological replicates to assess the activity of antioxidant enzymes, including SOD (U/g FW, EC 1.15.1.1), POD (U/g FW, EC 1.11.1.7), and CAT (nmol/min/g FW, EC 1.11.1.6), and to determine $\mathrm{H}_{2} \mathrm{O}_{2}$ content $(\mu \mathrm{mol} / \mathrm{g} \mathrm{FW})$, according to the instructions of a commercial chemical assay kit (Comin Biotechnology Co. Ltd., Suzhou, China) [76]. After one-way analysis of variance, treatment means were assessed by Duncan's multiple range test in SPSS Statistics version 17.0 and considered to be significantly different from controls at $P<0.05$.

\section{Determination of $\mathrm{Na}^{+}$and $\mathrm{K}^{+}$content}

Harvested roots were dried at $80^{\circ} \mathrm{C}$ for $48 \mathrm{~h}$. Then the roots were grind to powder, and internal ions were extracted with $1 \mathrm{M} \mathrm{HCl}$ for $12 \mathrm{~h}$. After the solution was filtered and volume to $50 \mathrm{~mL}, \mathrm{~K}^{+}$and $\mathrm{Na}^{+}$contents were 
measured with an atomic absorption spectrophotometer by flame mode [77].

\section{RNA extraction and CDNA library construction}

Total RNA extraction was performed from three biological replicates at $0 \mathrm{~h}, 6 \mathrm{~h}, 24 \mathrm{~h}$, and $72 \mathrm{~h}$ of $\mathrm{NaCl}$-treated $C$. inerme roots using the Column Plant RNA $\mathrm{OUT}_{\text {Extraction }}$ kit (TIANDZ, Beijing, China) and treated with DNase I to remove genomic DNA, as suggested by the manufacturer. The concentration and quality of each sample were determined by agarose electrophoresis or an Agilent 2100 bioanalyzer (Agilent Technologies, Palo Alto, CA, USA). mRNAs were purified from total RNA using magnetic beads with oligo (dT) and fragmented into small pieces (200-300 bp). Then, the cleaved RNA fragments were primed with random hexamer primer for first-strand cDNA synthesis and second-strand cDNA synthesis. After purification, end repair, and ligation to sequencing adapters, 12 cDNA libraries of three biological replicates for each treatment were construct using the Illumina HiSeq 2500 platform by Personal Biotechnology Co., Ltd. (Shanghai, China).

\section{Sequencing and functional annotation}

The percentage of unknown nucleotides as well as percentage of base recognition accuracy of more than $99.0 \%$ of bases (Q20) were calculated from raw reads. After cleaning the raw reads and discarding low quality reads, Trinity software (version 2.5.1, https://github.com/trinityrnaseq/trinityrnaseq/ wiki; accessed March 15, 2018) was used for de novo assembly of high-quality reads. To annotate sequences obtained by de novo assembly, assembled transcripts were aligned to NCBI non-redundant protein sequences (NR, http://ftp.ncbi. nlm.nih.gov/blast/db/FASTA/; accessed March 15, 2018), Gene Ontology (GO, (https://www.blast2go.com/; accessed March 15, 2018), Kyoto Encyclopedia of Genes and Genome (KEGG, KAAS (http://www.genome.jp/tools/kaas/; accessed March 15, 2018), evolutionary genealogy of genes: Nonsupervised Orthologous Groups (eggNOG, http://eggnog. embl.de/version_3.0; accessed March 15, 2018) and SwissProt (http://www.uniprot.org/help/uniprotkb; accessed March 15, 2018) using BLASTX with a significance threshold of $E \leq 10^{-5}$.

\section{Analysis of gene expression levels}

Gene expression levels were quantified by RNA-seq by Expectation Maximization (RSEM) software (http:// deweylab.github.io/RSEM/; accessed March 15, 2018). Gene expression level was calculated with the fragments per kilobase per transcript per million mapped reads method (FPKM). The number of transcripts after filtering was analyzed by density distribution and a boxplot graph to investigate the expression patterns among all samples. Pearson's correlation between samples was calculated based on FPKM results to determine the operational stability and reliability of the experiment.

\section{Identification and functional annotation of DEGs}

DEseq software (http://www.bioconductor.org/packages/release/bioc/html/DESeq.html; accessed March 15, 2018) was used to determine significant DEGs defined as a fold change (FC) $\geq 2$ and $P$ value $<0.05$ at $6 \mathrm{~h} / 0 \mathrm{~h}, 24 \mathrm{~h} / 0 \mathrm{~h}$, and $72 \mathrm{~h} /$ $0 \mathrm{~h}$. Hierarchical clustering was performed to determine the expression pattern of DEGs in the $0 \mathrm{~h}, 6 \mathrm{~h}, 24 \mathrm{~h}$, and $72 \mathrm{~h} \mathrm{li}$ braries using Pheatmap software (https://cran.r-project.org/ web/packages/pheatmap/index.html; accessed March 15, 2018). DEGs were mapped to each term of the GO database to detect significantly enriched GO terms with a corrected $P$ value $<0.05$ by the hypergeometric test method [78]. The number of DEGs at different levels was also calculated by the hypergeometric test to identify the main pathways involved in salt tolerance and to determine significantly enriched KEGG pathways at $P<0.05$ [79].

\section{qRT-PCR analysis}

Nine candidate DEGs, including seven up-regulated genes and two down-regulated genes in the enrichment KEGG pathway, were randomly chosen for qRT-PCR analysis to validate the transcriptomic data. qRT-PCR was performed with the ABI 7500 Real-time system (ABI, Alameda, CA, USA) using iTaq ${ }^{\text {mi }}$ Universal SYBR Green Supermix (Bio-Rad, Foster, CA, USA). Actin of $C$. inerme was quantified as an internal control and the $2^{-\Delta \Delta \mathrm{Ct}}$ method [80] was used to analyze differential expression. Gene-specific primers are listed in Additional file 5 : Table S5. Three biological replicates were performed for each candidate gene.

\section{Supplementary information}

Supplementary information accompanies this paper at https://doi.org/10. 1186/s12864-019-6098-y.

\footnotetext{
Additional files 1: Table S1. The significant enrichment $\mathrm{GO}$ terms at 6 h, $24 \mathrm{~h}$, and $72 \mathrm{~h}$. (XLSX $21 \mathrm{~kb}$ )

Additional files 2: Table S2. The significant enrichment KEGG pathway at $6 \mathrm{~h}, 24 \mathrm{~h}$, and $72 \mathrm{~h}$. (XLSX $16 \mathrm{~kb}$ )

Additional files 3: Table S3. The annotation DEGs on plant hormone signal transduction pathway. (XLSX $15 \mathrm{~kb}$ )

Additional files 4: Table S4. Genes related to antioxidant enzymes and ion transport. (XLSX $32 \mathrm{~kb}$ )

Additional files 5: Table S5. qRT-PCR primers. (XLSX $9 \mathrm{~kb}$ )

Additional files 6: Fig. S1. Density analysis of FPKM. (TIF 429 kb)

Additional files 7: Fig. S2. FPKM boxplot. (TIF $240 \mathrm{~kb}$ )

Additional files 8: Fig. S3. Correlation analysis of sample. (TIF $275 \mathrm{~kb}$ )

Additional files 9: Fig. S4. Plant hormone signal transduction pathway of DEGs at $6 \mathrm{~h}$ vs $0 \mathrm{~h}$. (TIF $496 \mathrm{~kb}$ )

Additional files 10: Fig. S5. Plant hormone signal transduction pathway of DEGs at $24 \mathrm{~h}$ vs $0 \mathrm{~h}$. (TIF $134 \mathrm{~kb}$ )
} 
Additional files 11: Fig. S6. Plant hormone signal transduction pathway of DEGs at $72 \mathrm{~h}$ vs $0 \mathrm{~h}$. (TIF $132 \mathrm{~kb}$ )

\section{Abbreviations}

ABA: Abscisic acid; BA: 6-Benzyladenine; CAT: Catalase;

CDNA: Complementary deoxyribonucleic acid; DEG: Differentially expressed gene; DW: Dry weight; eggNOG: Evolutionary genealogy of genes: Nonsupervised Orthologous Groups; ERF: Ethylene-responsive transcription factor; FC: Fold change; FPKM: Fragments per kilobases per million mapped reads; FW: Fresh weight; GO: Gene ontology; IBA: Indole-3-butyric acid; KEGG: Kyoto Encyclopedia of Genes and Genomes; MS: Murashige and Skoog; NAA: aNaphthaleneacetic acid; NCBI: National Center for Biotechnology Information; NR: NCBI non-redundant protein sequences; PCR: Polymerase chain reaction; POD: Peroxidase; qPCR: Quantitative PCR; RNA: Ribonucleic acid; RNAseq: High-throughput RNA-sequencing; ROS: Reactive oxygen species; RSEM: RNA-seq by Expectation Maximization; SA: Salicylic acid; SOD: Superoxide dismutase

\section{Acknowledgements}

We thank Personal Biotechnology Co., Ltd. for their skillful support in RNAsequencing.

\section{Authors' contributions}

YPX and HZL prepared samples for physiological analysis and RNA-seq. HFY and YYZ performed the statistical analysis on the RNA-seq data. BYG and MYN participated in the statistical analysis of physiological changes. YPX and HFY also involved in all statistical analysis and wrote the manuscript. SGJ, HR, $X H Z, Y L, S J Z, K L W, F Z$, JATS and GHM designed the experiment and provided guidance on the study. All authors wrote, read and approved the manuscript.

\section{Funding}

This work was financially supported by the National Key Research and Development Program of China (2016YFC1403000/2016YFC1403002), the Strategic Priority Research Program of the Chinese Academy of Sciences (XDA13020500) and the National Science and Technology Support Program (2015BAL04B04). The funding agencies had no role in the design, analysis, and interpretation of the data or writing of the manuscript.

\section{Availability of data and materials}

All data generated or analyzed during this study are included in this published article and its supplementary information files. The RNA-seq data has been deposited in the Sequence Read Archives Database (https://www. ncbi.nlm.nih.gov/sra/; accessed November 7, 2018) under accession number PRJNA504939 (https://www.ncbi.nlm.nih.gov/sra/PRJNA504939)

\section{Ethics approval and consent to participate}

Specific permission was not required for plant collection at the mentioned locations.

\section{Consent for publication}

Not applicable.

\section{Competing interests}

The authors declare that they have no competing interests.

\section{Author details}

${ }^{1}$ Guangdong Provincial Key Laboratory of Applied Botany, South China Botanical Garden, the Chinese Academy of Sciences, Guangzhou 510650, China. ${ }^{2}$ University of Chinese Academy of Sciences, Beijing 100039, China. ${ }^{3}$ Cash Crop Institute of Guangxi Academy of Agricultural Sciences, Nanning 30007, China. ${ }^{4}$ Miki-cho Post Office, P.O. Box 7, Ikenobe 3011-2, Miki-cho, Kagawa-ken 761-0799, Japan.

Received: 5 December 2018 Accepted: 11 September 2019 Published online: 10 October 2019

\section{References}

1. Rossatto T. Do Amaral MN, Benitez LC, Vighi IL, Braga EJB, de Magalhães Júnior AM, Maia MAC, da Silva pinto L. gene expression and activity of antioxidant enzymes in rice plants, cv. BRS AG, under saline stress. Physiol Mol Biol Plants. 2017;23(4):865-75.

2. Saini S, Kaur N, Pati PK. Reactive oxygen species dynamics in roots of salt sensitive and salt tolerant cultivars of rice. Anal Biochem. 2018;550:99-108.

3. Sarabi B, Bolandnazar S, Ghaderi N, Ghashghaie J. Genotypic differences in physiological and biochemical responses to salinity stress in melon (Cucumis melo L.) plants: prospects for selection of salt tolerant landraces. Plant Physiol Biochem. 2017;119:294-311.

4. AbdElgawad H, Zinta G, Hegab MM, Pandey R, Asard H, Abuelsoud W. High salinity induces different oxidative stress and antioxidant responses in maize seedlings organs. Front Plant Sci. 2016;7:276

5. Wei QH, Luo QC, Wang RB, Zhang F, He Y, Zhang Y, Qiu D, Li KX, Chang JL, Yang GX, He GY. A wheat R2R3-type MYB transcription factor TaODORANT1 positively regulates drought and salt stress responses in transgenic tobacco plants. Front Plant Sci. 2017:8:1374.

6. Rouphael Y, Raimondi G, Lucini L, Carillo P, Kyriacou MC, Colla G, Cirillo V, Pannico A, El-Nakhel C, De Pascale S. Physiological and metabolic responses triggered by omeprazole improve tomato plant tolerance to $\mathrm{NaCl}$ stress. Front Plant Sci. 2018;9:249.

7. Borsani $O$, Valpuesta $V$, Botella MA. Developing salt tolerant plants in a new century: a molecular biology approach. Plant Cell Tiss Org. 2003;73(2):101-15.

8. Mallik S, Nayak M, Sahu BB, Panigrahi AK, Shaw BP. Response of antioxidant enzymes to high $\mathrm{NaCl}$ concentration in different salt-tolerant plants. Biol Plant. 2011;55(1):191-5.

9. Kumari A, Das P, Parida AK, Agarwal PK. Proteomics, metabolomics, and ionomics perspectives of salinity tolerance in halophytes. Front Plant Sci. 2015;6:537.

10. Ruan CJ. Teixeira da Silva JA. Metabolomics: creating new potentials for unraveling the mechanisms in response to salt and drought stress and for the biotechnological improvement of xero-halophytes. Crit Rev Biotechnol. 2011;31(2):153-69.

11. Volkov $V$, Amtmann A. Thellungiella halophila, a salt-tolerant relative of Arabidopsis thaliana, has specific root ion-channel features supporting $\mathrm{K}^{+}$/ $\mathrm{Na}^{+}$homeostasis under salinity stress. Plant J. 2006:48(3):342-53.

12. Taji T, Komatsu K, Katori T, Kawasaki Y, Sakata Y, Tanaka S, Kobayashi M, Toyoda A, Seki M, Shinozaki K. Comparative genomic analysis of 1047 completely sequenced cDNAs from an Arabidopsis-related model halophyte, Thellungiella halophila BMC Plant Biol 2010, 10:261.

13. Wang JC, Li BC, Meng YX, Ma XO, Lai Y, Si EJ, Yang K, Ren PR, Shang XW, Wang HJ. Transcriptomic profiling of the salt-stress response in the halophyte Halogeton glomeratus. BMC Genomics. 2015;16:169.

14. Jin HX, Dong DK, Yang QH, Zhu DH. Salt-responsive transcriptome profiling of Suaeda glauca via RNA sequencing. PLoS One. 2016;11(3):e0150504.

15. Rahman MM, Rahman MA, Miah MG, Saha SR, Karim MA, Mostofa MG. Mechanistic insight into salt tolerance of Acacia auriculiformis: the importance of ion selectivity, osmoprotection, tissue tolerance, and $\mathrm{Na}^{+}$ exclusion. Front Plant Sci. 2017:8:155.

16. Gharbi E, Martínez JP, Benahmed H, Hichri I, Dobrev PI, Motyka V, Quinet M, Lutts S. Phytohormone profiling in relation to osmotic adjustment in $\mathrm{NaCl}$ treated plants of the halophyte tomato wild relative species Solanum chilense comparatively to the cultivated glycophyte Solanum lycopersicum. Plant Sci. 2017;258:77-89.

17. Al Hassan M, Estrelles E, Soriano P, López-Gresa MP, Bellés JM, Boscaiu M, Vicente O. Unraveling salt tolerance mechanisms in halophytes: a comparative study on four Mediterranean Limonium species with different geographic distribution patterns. Front Plant Sci. 2017;8:1438.

18. Nikalje GC, Variyar PS, Joshi MV, Nikam TD, Suprasanna P. Temporal and spatial changes in ion homeostasis, antioxidant defense and accumulation of flavonoids and glycolipid in a halophyte Sesuvium portulacastrum (L.) L. PLoS One. 2018, 13(4):e0193394.

19. Wang J, Cheng G, Wang C, He ZZ, Lan XX, Zhang SY, Lan HY. The bHLH transcription factor $\mathrm{CgbHLH0O1}$ is a potential interaction partner of CDPK in halophyte Chenopodium glaucum. Sci Rep. 2017;7(1):8441.

20. Tang J, Liu QQ, Yuan HY, Zhang YX, Wang WL, Huang SZ. Molecular cloning and characterization of a novel salt-specific responsive WRKY transcription factor gene IIWRKY2 from the halophyte Iris lactea var. chinensis. Genes Genomics. 2018;40(8):893-903.

21. Rauf M, Shahzad K, Ali R, Ahmad M, Habib I, Mansoor S, Berkowitz GA Saeed NA. Cloning and characterization of $\mathrm{Na}^{+} / \mathrm{H}^{+}$antiporter ( $L F N H X I$ ) gene from a halophyte grass Leptochloa fusca for drought and salt tolerance. Mol Biol Rep. 2014;41(3):1669-82. 
22. Wang HY, Tang XL, Shao CY, Shao HB, Wang HL. Molecular cloning and bioinformatics analysis of a new plasma membrane $\mathrm{Na}^{+} / \mathrm{H}^{+}$antiporter gene from the halophyte Kosteletzkya virginica. Sci World J. 2014;2014:141675.

23. Tiwari V, Chaturvedi AK, Mishra A, Jha B. The transcriptional regulatory mechanism of the peroxisomal ascorbate peroxidase ( $P A P X)$ gene cloned from an extreme halophyte, Salicornia brachiata Plant Cell Physiol 2014, 55(1):201-217

24. Mohamed E, Matsuda R, El-Khatib AA, Takechi K, Takano H, Takio S. Characterization of the superoxide dismutase genes of the halophyte Suaeda maritima in Japan and Egypt. Plant Cell Rep. 2015;34(12):2099-110.

25. Parveen M, Khanam Z, Ali M, Rahman SZ. A novel lupene-type triterpenic glucoside from the leaves of Clerodendrum inerme. Nat Prod Res. 2010;24(2): 167-76.

26. Shahabuddin SK, Munikishore R, Trimurtulu G, Gunasekar D, Devillee A, Bodo B. Two new chalcones from the flowers of Clerodendrum inerme. Nat Prod Commun. 2013;8(4):459-60.

27. Nan HH, Wu J, Zhang S. A new phenylethanoid glycoside from Clerodendrum inerme. Pharmazie. 2005;60(10):798-9

28. Srisook K, Srisook E, Nachaiyo W, Chan-In M, Thongbai J, Wongyoo K, Chawsuanthong S, Wannasri K, Intasuwan S, Watcharanawee K. Bioassayguided isolation and mechanistic action of anti-inflammatory agents from Clerodendrum inerme leaves. J Ethnopharmacol. 2015;165:94-102.

29. Chen HL, Lee HJ, Huang WJ, Chou JF, Fan PC, Du JC, Ku YL, Chiou LC. Clerodendrum inerme leaf extract alleviates animal behaviors, hyperlocomotion, and prepulse inhibition disruptions, mimicking tourette syndrome and schizophrenia. Evid Based Complement Alternat Med. 2012; 2012:284301.

30. Gopal N, Sengottuvelu S. Hepatoprotective activity of Clerodendrum inerme against $\mathrm{CCL}_{4}$ induced hepatic injury in rats. Fitoterapia. 2008;79(1):24-6.

31. Saenger $P$. The mangrove Flora. In: Mangrove ecology, Silviculture and conservation. Dordrecht: Springer Netherlands; 2002. p. 11-47.

32. Khan MA, Qaiser M. Halophytes of Pakistan: characteristics, distribution and potential economic usages. In: Sabkha Ecosystems: Volume II: West and Central Asia. Edited by Khan MA, Böer B, Kust GS, Barth H-J. Dordrecht: Springer Netherlands; 2006: 129-153.

33. Basyuni M, Kinjo Y, Baba S, Shinzato N, Iwasaki H, Siregar EBM, Oku H. Isolation of salt stress tolerance genes from roots of mangrove plant, Rhizophora stylosa Griff., using PCR-based suppression subtractive hybridization. Plant Mol Biol Rep. 2011;29(3):533-43.

34. Wang F, Wu QH, Zhang Z, Chen SF, Zhou RC. Cloning, expression, and characterization of iron superoxide dismutase in Sonneratia alba, a highly salt tolerant mangrove tree. Protein J. 2013;32(4):259-65.

35. Krishnamurthy P, Mohanty B, Wijaya E, Lee DY, Lim TM, Lin Q, Xu J, Loh CS, Kumar PP. Transcriptomics analysis of salt stress tolerance in the roots of the mangrove Avicennia officinalis. Sci Rep. 2017;7(1):10031.

36. Diray-Arce J, Clement M, Gul B, Khan MA, Nielsen BL. Transcriptome assembly, profiling and differential gene expression analysis of the halophyte Suaeda fruticosa provides insights into salt tolerance. BMC Genomics. 2015;16(1):353.

37. Hess M, Wildhagen $H$, Junker LV, Ensminger I. Transcriptome responses to temperature, water availability and photoperiod are conserved among mature trees of two divergent Douglas-fir provenances from a coastal and an interior habitat. BMC Genomics. 2016;17(1):682.

38. Sharma R, Mishra M, Gupta B, Parsania C, Singla-Pareek SL, Pareek A. De novo assembly and characterization of stress transcriptome in a salinitytolerant variety CS52 of Brassica juncea. PLoS One. 2015;10(5):e0126783.

39. An YM, Song LL, Liu YR, Shu YJ, Guo CH. De novo transcriptional analysis of alfalfa in response to saline-alkaline stress. Front Plant Sci. 2016;7:931.

40. Zhou XG, Ren LF, Meng QS, Li YT, Yu Y, Yu J. The next-generation sequencing technology and application. Protein \& Cell. 2010;1(6):520-36.

41. Gharat SA, Parmar S, Tambat S, Vasudevan M, Shaw BP. Transcriptome analysis of the response to $\mathrm{NaCl}$ in Suaeda maritima provides an insight into salt tolerance mechanisms in halophytes. PLoS One. 2016;11(9): e0163485.

42. Skorupa M, Gołębiewski M, Domagalski K, Kurnik K, Abu Nahia K, Złoch M, Tretyn A, Tyburski J. Transcriptomic profiling of the salt stress response in excised leaves of the halophyte Beta vulgaris ssp. maritima. Plant Sci. 2016; 243:56-70.

43. Li L, Li MM, Qi XW, Tang XL, Zhou YF. De novo transcriptome sequencing and analysis of genes related to salt stress response in Glehnia littoralis. Peer J. 2018;6:e5681.
44. Chen S, Jiang J, Li HY, Liu GF. The salt-responsive transcriptome of Populus simonii × Populus nigra via DGE. Gene. 2012:504(2):203-12.

45. Liu CH, Lu RJ, Guo GM, He T, Li YB, Xu HW, Gao RH, Chen ZW, Huang JH. Transcriptome analysis reveals translational regulation in barley microsporederived embryogenic callus under salt stress. Plant Cell Rep. 2016;35(8): 1719-28.

46. Feng JJ, Wang JH, Fan PX, Jia WT, Nie LL, Jiang P, Chen XY, LV SL, Wan LC, Chang S, Li SZ, Li YX. High-throughput deep sequencing reveals that microRNAs play important roles in salt tolerance of euhalophyte Salicornia europaea. BMC Plant Biol. 2015;15(1):63.

47. Wang JW, Xu M, Gu YC, Xu LA. Differentially expressed gene analysis of Tamarix chinensis provides insights into $\mathrm{NaCl}$-stress response. Trees. 2017; 31(2):645-58.

48. Gruber V, Blanchet S, Diet A, Zahaf O, Boualem A, Kakar K, Alunni B, Udvardi M, Frugier F, Crespi M. Identification of transcription factors involved in root apex responses to salt stress in Medicago truncatula. Mol Gen Genomics. 2009:281(1):55-66.

49. Wang HM, Xiao XR, Yang MY, Gao ZL, Zang J, Fu XM, Chen YH. Effects of salt stress on antioxidant defense system in the root of Kandelia candel. Bot Stud. 2014;55(1):57.

50. Wei SW, Wang LM, Zhang YD, Huang DF. Identification of early response genes to salt stress in roots of melon (Cucumis melo L.) seedlings. Mol Biol Rep. 2013;40(4):2915-26.

51. Zheng LY, Meng Y, Ma J, Zhao XL, Cheng TL, Ji J, Chang EM, Meng C, Deng $\mathrm{N}$, Chen LZ, Shi SQ, Jiang ZP. Transcriptomic analysis reveals importance of ROS and phytohormones in response to short-term salinity stress in Populus tomentosa. Front Plant Sci. 2015;6:678.

52. Xie Q, Niu J, Xu XL, Xu LX, Zhang YB, Fan B, Liang XH, Zhang L, Yin SX, Han LB. De novo assembly of the Japanese lawngrass (Zoysia japonica Steud.) root transcriptome and identification of candidate unigenes related to early responses under salt stress. Front Plant Sci. 2015, 6:610

53. Hu GF, Liu YM, Duo TQ, Zhao BY, Cui GW, Ji J, Kuang X, Ervin EH, Zhang XZ. Antioxidant metabolism variation associated with alkali-salt tolerance in thirty switchgrass (Panicum virgatum) lines. PLoS One. 2018;13(6):e0199681.

54. Ghaderi N, Hatami MR, Mozafari A, Siosehmardeh A. Change in antioxidant enzymes activity and some morpho-physiological characteristics of strawberry under long-term salt stress. Physiol Mol Biol Plants. 2018;24(5):833-43.

55. Mittler R, Vanderauwera S, Gollery M, Van Breusegem F. Reactive oxygen gene network of plants. Trends Plant Sci. 2004;9(10):490-8.

56. Ahanger MA, Tomar NS, Tittal M, Argal S, Agarwal RM. Plant growth under water/salt stress: ROS production; antioxidants and significance of added potassium under such conditions. Physiol Mol Biol Plants. 2017;23(4):731-44.

57. Nikalje GC, Mirajkar SJ, Nikam TD, Suprasanna P. Multifarious role of ROS in halophytes: Signaling and defense. In: Abiotic stress-mediated sensing and signaling in plants: An Omics Perspective. Edited by Zargar SM, Zargar MY. Singapore: Springer Singapore; 2018: 207-223.

58. Zhang $Y$, Fang J, Wu $X$, Dong $\mathrm{L}$. $\mathrm{Na}^{+} / \mathrm{K}^{+}$balance and transport regulatory mechanisms in weedy and cultivated rice (Oryza sativa L.) under salt stress. BMC Plant Biol. 2018, 18(1):375

59. Sun XC, Xu L, Wang Y, Luo XB, Zhu XW, Kinuthia KB, Nie SS, Feng HY, Li C, Liu LW. Transcriptome-based gene expression profiling identifies differentially expressed genes critical for salt stress response in radish (Raphanus sativus L.). Plant Cell Rep. 2016;35(2):329-46.

60. Zhang AQ, Han DM, Wang Y, Mu HF, Zhang T, Yan XF, Pang QY. Transcriptomic and proteomic feature of salt stress-regulated network in Jerusalem artichoke (Helianthus tuberosus L.) root based on de novo assembly sequencing analysis. Planta. 2018;247(3):715-32.

61. Liu QQ, Tang J, Wang WL, Zhang YX, Yuan HY, Huang SZ. Transcriptome analysis reveals complex response of the medicinal/ornamental halophyte Iris halophila pall. To high environmental salinity. Ecotoxicol Environ Saf. 2018:165:250-60.

62. Wang MQ, Wang YF, Zhang YF, Li CX, Gong SC, Yan SQ, Li GL, Hu GH, Ren HL, Yang JF, Yu T, Yang KJ. Comparative transcriptome analysis of salt-sensitive and salt-tolerant maize reveals potential mechanisms to enhance salt resistance. Genes Genom. 2019; https://doi.org/10.1007/s13258-019-00793-y.

63. Mizoi J, Shinozaki K, Yamaguchi-Shinozaki K. AP2/ERF family transcription factors in plant abiotic stress responses. Biochim Biophys Acta. 2012;1819(2):86-96.

64. Rong W, Qi L, Wang AY, Ye XG, Du LP, Liang HX, Xin ZY, Zhang ZY. The ERF transcription factor TaERF3 promotes tolerance to salt and drought stresses in wheat. Plant Biotechnol J. 2014;12(4):468-79. 
65. Yao WJ, Wang L, Zhou BR, Wang SJ, Li RH, Jiang TB. Over-expression of poplar transcription factor ERF76 gene confers salt tolerance in transgenic tobacco. J Plant Physiol. 2016;198:23-31.

66. Agarwal P, Agarwal PK. Pathogenesis related-10 proteins are small, structurally similar but with diverse role in stress signaling. Mol Biol Rep. 2014;41 (2):599-611.

67. Seo PJ, Lee AK, Xiang F, Park CM. Molecular and functional profiling of Arabidopsis pathogenesis-related genes: insights into their roles in salt response of seed germination. Plant Cell Physiol. 2008;49(3):334-44.

68. Tachi H, Fukuda-Yamada K, Kojima T, Shiraiwa M, Takahara H. Molecular characterization of a novel soybean gene encoding a neutral PR-5 protein induced by high-salt stress. Plant Physiol Biochem. 2009;47(1):73-9.

69. Jain S, Kumar D, Jain M, Chaudhary P, Deswal R, Sarin NB. Ectopic overexpression of a salt stress-induced pathogenesis-related class 10 protein (PR10) gene from peanut (Arachis hypogaea L.) affords broad spectrum abiotic stress tolerance in transgenic tobacco. Plant Cell Tiss Org. 2012;109(1):19-31.

70. Rustagi A, Jain S, Kumar D, Shekhar S, Jain M, Bhat V, Sarin NB. High efficiency transformation of banana [Musa acuminata L. CV. Matti (AA)] for enhanced tolerance to salt and drought stress through overexpression of a peanut salinity-induced pathogenesis-related class 10 protein. Mol Biotechnol. 2015;57(1):27-35.

71. Wang SK, Bai YH, Shen CJ, Wu YR, Zhang SN, Jiang DA, Guilfoyle TJ, Chen M, Qi YH. Auxin-related gene families in abiotic stress response in Sorghum bicolor. Func Integr Genomics. 2010;10(4):533-46.

72. Jain M, Khurana JP. Transcript profiling reveals diverse roles of auxinresponsive genes during reproductive development and abiotic stress in rice. FEBS J. 2009:276(11):3148-62.

73. Liu XH, Zhang RH, Ou HP, Gui YY, Wei JJ, Zhou H, Tan HW, Li YR. Comprehensive transcriptome analysis reveals genes in response to water deficit in the leaves of Saccharum narenga (Nees ex Steud.) hack. BMC Plant Biol. 2018, 18(1):250.

74. Murashige T, Skoog F. A revised medium for rapid growth and bioassays with tobacco tissue cultures. Physiol Plant. 1962;15:473-97.

75. Nataraj M, Kher MM. Teixeira da Silva JA. Micropropagation of Clerodendrum L. species: a review. Rendiconti Lincei. 2016;27(2):169-79.

76. Wang B, Guo X, Zhao PJ, Ruan MB, Yu XL, Zou LP, Yang YL, Li X, Deng DL, Xiao JX, Xiao YW, Hu CJ, Wang X, Wang XL, Wang WQ, Peng M. Molecular diversity analysis, drought related marker-traits association mapping and discovery of excellent alleles for 100-day old plants by EST-SSRs in cassava germplasms (Manihot esculenta Cranz). PLoS One. 2017;12(5):e0177456.

77. Takahashi R, Nishio T, Ichizen N, Takano T. Salt-tolerant reed plants contain lower $\mathrm{Na}^{+}$and higher $\mathrm{K}^{+}$than salt-sensitive reed plants. Acta Physiol Plant. 2007:29(5):431-8.

78. Eden E, Navon R, Steinfeld I, Lipson D, Yakhini Z. Gorilla: a tool for discovery and visualization of enriched $\mathrm{GO}$ terms in ranked gene lists. BMC Bioinformatics. 2009;10:48.

79. Mao XZ, Cai T, Olyarchuk JG, Wei LP. Automated genome annotation and pathway identification using the KEGG Orthology (KO) as a controlled vocabulary. Bioinformatics. 2005:21(19):3787-93.

80. Livak KJ, Schmittgen TD. Analysis of relative gene expression data using realtime quantitative PCR and the $2^{--\Delta \Delta C T}$ method. Methods. 2001;25(4):402-8.

\section{Publisher's Note}

Springer Nature remains neutral with regard to jurisdictional claims in published maps and institutional affiliations.

Ready to submit your research? Choose BMC and benefit from:

- fast, convenient online submission

- thorough peer review by experienced researchers in your field

- rapid publication on acceptance

- support for research data, including large and complex data types

- gold Open Access which fosters wider collaboration and increased citations

- maximum visibility for your research: over $100 \mathrm{M}$ website views per year

At BMC, research is always in progress.

Learn more biomedcentral.com/submissions 